\title{
Everyday Jazz Lives: A photographic project on contemporary jazz musicians lives in Birmingham
}

\section{Pedro Cravinho ${ }^{1}$}

Research Fellow, Birmingham Centre for Media and Cultural Research \&

Keeper of the Archives, Faculty of Arts, Design and Media, Birmingham City University, UK pedro.cravinho@bcu.ac.uk

\section{Brian Homer ${ }^{2}$}

Freelancer photographer, Birmingham, UK brian@brianhomer.com

\section{Introduction}

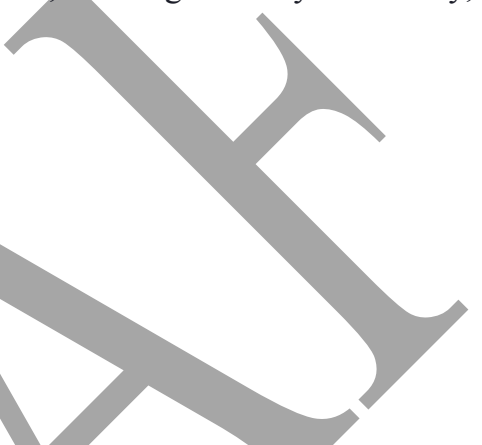

This article examines fragments of a local jazz scene through photographs (Schwartz, 1989: 119). ${ }^{3}$ It is the result of a collaborative pilot research project entitled 'Everyday Jazz Lives: A photographic project on contemporary jazz musicians lives in Birmingham" that took place at Birmingham Centre for Media and Cultural Research, and brought together an academic and a photographer. ${ }^{4}$ The ethnomusicologist Pedro Cravinho, who conducted an initial semistructured interview to each of the participants in the project: Alicia Gardner-Trejo, Chris Young, David Austin Grey, Joey Walter, Ruth Angell, and Xhosa Cole. And Brian Homer, a local freelance photographer, who carried out the photographic sessions. ${ }^{5}$

\footnotetext{
${ }^{1}$ Dr Pedro Cravinho, researches and writes about jazz, media, and archives. Currently, he is the Keeper of the Archives at the Faculty of Arts, Design \& Media, and a Research Fellow at Birmingham Centre for Media and Cultural Research. Cravinho research interests include the twentieth-century jazz diaspora social, political and musical history. He belongs to the editorial board of the new European jazz research journal, Jazz-hitz (2018, Musikene), and is also a Trustee for the National Jazz Archive UK, board member of the Duke Ellington Society UK, and co-founder and board member of the Portuguese Jazz Network - Portugal Jazz. As an author and editor advisor, Cravinho has collaborated in several international publications, such as Jazz and Totalitarianism (2017, Routledge), The History of European Jazz: The Music, Musicians and Audience in Context (2018, Equinox), and The [Oxford] History of Jazz in Europe (forthcoming, Oxford University Press). Currently is working in his monograph that explores the cultural politics of jazz on television in Portugal.

${ }^{2}$ Brian Homer is a photographer, designer and writer. He was part of the original Handsworth Self Portrait project with Derek Bishton and John Reardon in 1979, with whom he also co-founded Ten8 international photography magazine. Homer has co-curated many self-portrait photography projects including 1000 images for the opening of the Library of Birmingham and a set for the 50th Anniversary of Telford. Between 2012 and 2018 he was on the board of Birmingham Jazz, and currently is an active freelancer photographer documenting the local jazz scene. His photographs and reviews have appeared in Jazzwise, London Jazz News and UK Vibe. Homer has also taken publicity photographs for jazz artists and projects such as Trish Clowes' My Iris, John O'Gallagher and Pigfoot.

${ }^{3}$ The authors would like to thank all the musicians that participated in the 'Everyday Jazz Lives' research project.

${ }^{4}$ An early version of this article was presented as a paper at the Sixth Rhythm Changes Conference: Jazz Journeys (April 2019), organised by the University of Music and Performing Arts Graz in Austria. The authors would like to thank Nick Gebhardt for the invitation to contribute to the Jazz and Everyday Aesthetics special issue. The aforementioned paper was expanded, revised and adapted especially in terms of notes and references.

${ }^{5}$ Dr Pedro Cravinho, has been conducting original research on Jazz in Birmingham since mid-2015, and Brian Homer, works as a freelance photographer deeply connected with local jazz scene over decades.
} 
As Ian Jeffery suggests, photographs "are understandable fragments" that carry with them "an invitation to reflect and even reconstruct" in the mind of the viewers (Jeffrey, 1992: 351). In part, given the capacity of photographs to trigger the imagination due to the "very incompleteness of the information one is able to gather" (Lofland, 1998: 81) implying a deeper binary between the invisible, what can be perceived in a photograph, and it is visible, what a photograph represents (Ings 2003). However, as fragments, photographs of contemporary Birmingham's jazz musicians as people, not just performers, in the context of their everyday lives can also been understood as records of intention illuminating how musicians' view themselves, the local jazz scene, and how they negotiate their lives while expanding their music. More broadly, as Tina Campt observes,

"The question of why a photograph was made involves understanding the social, cultural and historical relationships figured in the image, as well as a larger set of relationships outside and beyond the frame - relationships we might think of as social life of the photo. The social life of the photo includes the intentions of both sitters and photographers as reflected in their decision to take particular kind of pictures. It also involves reflecting historically on what those images say about these individuals aspired to be; how they wanted to be seen; what they sought to represent and articulate through them; and what they attempted or intended to project or portray (Campt, 2012: 6).

By exploring how photography acts rather than just "a transparent account of reality" (Sontag, 2003: 81) our pilot-project looked behind the usual stereotypes of gigging musicians making use of photography as research output. Linking Campt's argument, our focus was on the off-stage living experiences of six local musicians. How should we capture their everyday lives and hindrances they faced in progressing their musical careers? We argue that it is important that "such photographs function as image and practices of social and cultural enunciation that exceed their biographical detail" (Campt, 2012: 196). In the 'jazz world', photographs have been historically used as works of art, produced by photographers-artists, adding a significant contribution to the dissemination of the music globally. Although we acknowledge to the importance of the use of photographs as visual documentation of distinct jazz scenes globally across different generations. We try to shift our focus, by capturing our participants "as people, not just performers" in their everyday lives (Garin, 1995: 6).

However, as Schwartz observes, given its polysemic characteristic, "the viewing process [of a photograph] is a dynamic interaction between the photographer, the spectator, and the image; meaning is actively constructed, not passively received" (Schwartz, 1989: 120). The photograph 'is not a 'message' in the usual sense. It is, instead, the raw material for an infinite number of messages which each viewer can construct for himself" (Byers, 
1966: 31). Put another way, such approach "understands photographs as recording a series of choices that construct complex accounts of the social relations they depict" (Campt, 2012: 7).

Building upon those principles we structured our project into two stages. An initial one, conducting semi-structured interviews to each of the six participants all former students at the Royal Birmingham Conservatoire, which was followed by several photograph sessions. ${ }^{6}$ Each of those sessions it was perceived as an encounter that produces points of reflection and interrogations - capturing fragments of particular moments -, revealing participants social dynamics, constraints facing their musical careers, and perceptions about local jazz scene. ${ }^{7}$

\section{Jazz photography}

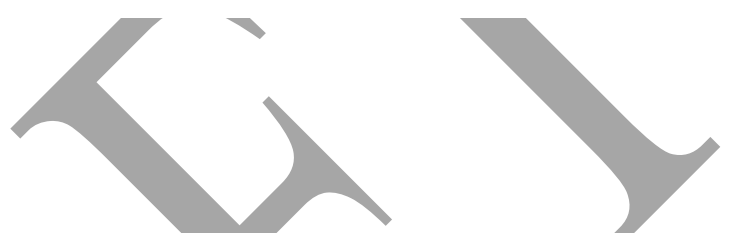

One could argue that connexions between photographers and jazz musicians have been continued throughout the decades. In Gabbard's words, "the best place to find compelling images of jazz is photography" (Gabbard, 2002: 337). In fact, "photographers had made jazz a subject from the earliest days of the music", either "in the service for magazines such as Down Beat or Life or record companies such as Blue Note" (Cawthra, 2011: 6).

Photographers such as Francis Wolf, Bill Gottlieb, Milt Hilton, Herman Leonard, and Lee E. Tanner, amongst many others also gave a significant contribution to the creation of "a mythology of jazz genius" (Cawthra, 2011: 6). Either taken in the night-clubs, concert halls, festivals, and recording studios or album sleeves, jazz photography helped to shape the visual perceptions of the music and disseminate jazz artists within the diasporic communities throughout the past century. Many of these photographic outputs are photographs of gigs, recording sessions or portraits. However there are photographers such as Bill Claxton, Roy DeCaravara, Dennis Stock, Lee Friedlander, Val Wilmer and others who looked at a wider view of musicians, but these images arguably are not as prominent in the imagery of jazz.

Regarding the Birmingham jazz scene, since the 1960s, photographer Jim Simpson has played a major role in capturing some of the 'great' jazz, and rhythm and blues artists visiting the city. ${ }^{8}$ Over decades he has photographed vast number of visiting national and international artists, including Nina Simone, Little Richard, Muddy Waters, BB King, Buddy

\footnotetext{
${ }^{6}$ On 24 September 2017 the Birmingham Conservatoire was granted Royal status by Queen Elizabeth II.

7 (Schwartz, 1989: 119).

${ }^{8}$ For photographic publications on Birmingham's contemporary jazz scene, see Escritt (2009a, 2009b, 2010a, and 2010b).
} 
Guy among many other. Simpson started as amateur photographer with his Zeiss Ikon, before he began working for Midland Beat magazine, writing and photographing the local music scene (Simpson and Simpson, 2019). ${ }^{9}$ Later with his Birmingham based company Big Bear, an independent record label and booking agency, Simpson has been organising a significant jazz festival in the city since $1985 .^{10}$

Locally, another important contribution was by Russ Escritt (b. 1956 - d. 2012). Escritt was a trade union official by day and a dedicated amateur photographer in his spare time. From the mid-1990s until 2012, combining his love of jazz with his interest in photography and began photographing David Murray playing with Andy Hamilton in Bearwood before starting photographing jazz gigs around Birmingham. Escritt initially worked exclusively in black and white, turning to colour in 2006. His work has been exhibited at several local venues, such as the Midlands Arts Centre, The Drum and Symphony Hall. Additional, Escritt's photographs have appeared in magazines such as The Wire and Jazzwise, as well as featuring on CDs sleeves.

Besides the works of Simpson and Escritt, it is important to highlight Garry Corbett, Bill Shakespeare, Brian Homer and John Watson, who have also been capturing the vibrant local jazz scene, including Birmingham Jazz and Jazzlines, over the past decades. ${ }^{11}$ But again, most of those are photographs of gigs. Photographs of local musicians in their daily off-stage activities has not received similar attention.

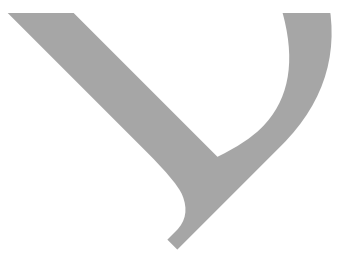

\footnotetext{
${ }^{9}$ Since 1987, the Simpson's Big Bear Music Group is also responsible for the publication of the bi-monthly 36page magazine The Jazz Rag. More recently, Simpson has published his memoirs. For further discussion on this topic see Simpson and Simpson (2019).

${ }^{10}$ In the summer of 1984, a significant jazz event took place in Birmingham. A jam session under the banner "The M\&B Jam Session" took place in the Cannon Hill Park, Edgbaston. "The event was so successful that it provided the inspiration for a wider and more ambitious event that has, in a mere twelve months, mushroomed into the inaugural Birmingham Jazz Festival" (Simpson, 1985: 5). In the following year, between 11 of 18 September 1985, it was launched the first Birmingham Jazz Festival. After three years of continuous success the festival was rebranded as Birmingham International Jazz Festival. Later as Birmingham International Jazz and Blues Festival. More recently, it was rebranded first as Birmingham and Solihull Jazz Festival, and later as Birmingham, Solihull and Sandwell Jazz Festival. In 2019, the festival took place between $17^{\text {th }}$ and $26^{\text {th }}$ of July and it was announced as the Birmingham, Sandwell \& Westside Jazz Festival.

${ }^{11}$ For further details, see Garry Corbett at https://www.flickr.com/people/bluejazzbuddha/; Bill Shakespeare at https://www.flickr.com/people/billtoview/; and John Watson at http://www.jazzcamera.co.uk/ and Watson (2011). Birmingham Jazz was the first local promoter of contemporary jazz in the city and was founded in 1976 by a group of aficionados including George West. In 2012 Birmingham Jazz continued as a voluntary organisation while the regular funding and staff moved to Town Hall Symphony Hall as Jazzlines.
} 


\section{Approach}

As a collaborative pilot research project our aim was to focus on contemporary jazz musicians in Birmingham in the context of their everyday lives, the local jazz scene, and how they negotiate their lives while developing their careers. The approach we took was to combine photography with investigating musicians' view of themselves, and the challenges they face in balancing musical and other professional activities. In planning the project we were restricted to six participant local musicians, but within that we took care to select a group that was as representative as possible of gender, career stage, and ethnicity. We approached several potential candidates and the group that agree to participate was Alicia Gardner-Trejo, Chris Young, David Austin Grey, Joey Walter, Ruth Angell, and Xhosa Cole.

The methodology used comprised an initial semi-structed interview with each participant addressing their personal journeys in education and music, their professional career and the local jazz scene. All the interviews were recorded in both sound and video. The outcomes from the interviews included significant insights into the participants personal lives and provided some opportunities to be explored photographically. This resulted in several distinct collaborative photographic sessions or photographs that were informed by the interviews. After fieldwork, we transcribed and analysed the interviews and selected quotes to inform the fragments (photographs) as 'narratives' of participants lives (Price 1994).

\section{Case studies:}

\section{Participant 1. Alicia Gardener-Trejo}

Baritone saxophonist/composer Alicia Gardener-Trejo has been active in Birmingham's jazz and improvised music scenes for over ten years. ${ }^{12}$ She has played regularly across the UK with bands including Sid Peacock's Surge, Bostin' Brass, the Samantha Wright Quintet and Birmingham Improvisors' Orchestra directed by Mark Sanders, and with some of UK's finest jazz musicians. ${ }^{13}$ Alicia has appeared on Birmingham Jazz Orchestra's critically acclaimed albums Burns and Rough Boundaries. As well as writing and arranging for her ensembles, Alicia has recently received commissions for Silent Monkey's Four Susans project and the

\footnotetext{
${ }^{12}$ For further details, see the artist's webpage at https://www.agardenertrejomusic.com/projects.

${ }^{13}$ Musicians such as Percy Pursglove, Jeff Williams, Paul Dunmall, Jason Singh, John O'Gallagher with BJO and played alongside jazz 'legends' Norma Winstone, John Taylor \& Gary Smulyan whilst studying at Birmingham Conservatoire, among many others.
} 
Greater Manchester Hub Orchestra. Her eleven-piece ensemble 'Bobtail' recorded their debut EP Frolic in 2016 at Symphony Hall. ${ }^{14}$ Alicia is proud to have been supported by Jazzlines THSH 'Women in Jazz'.

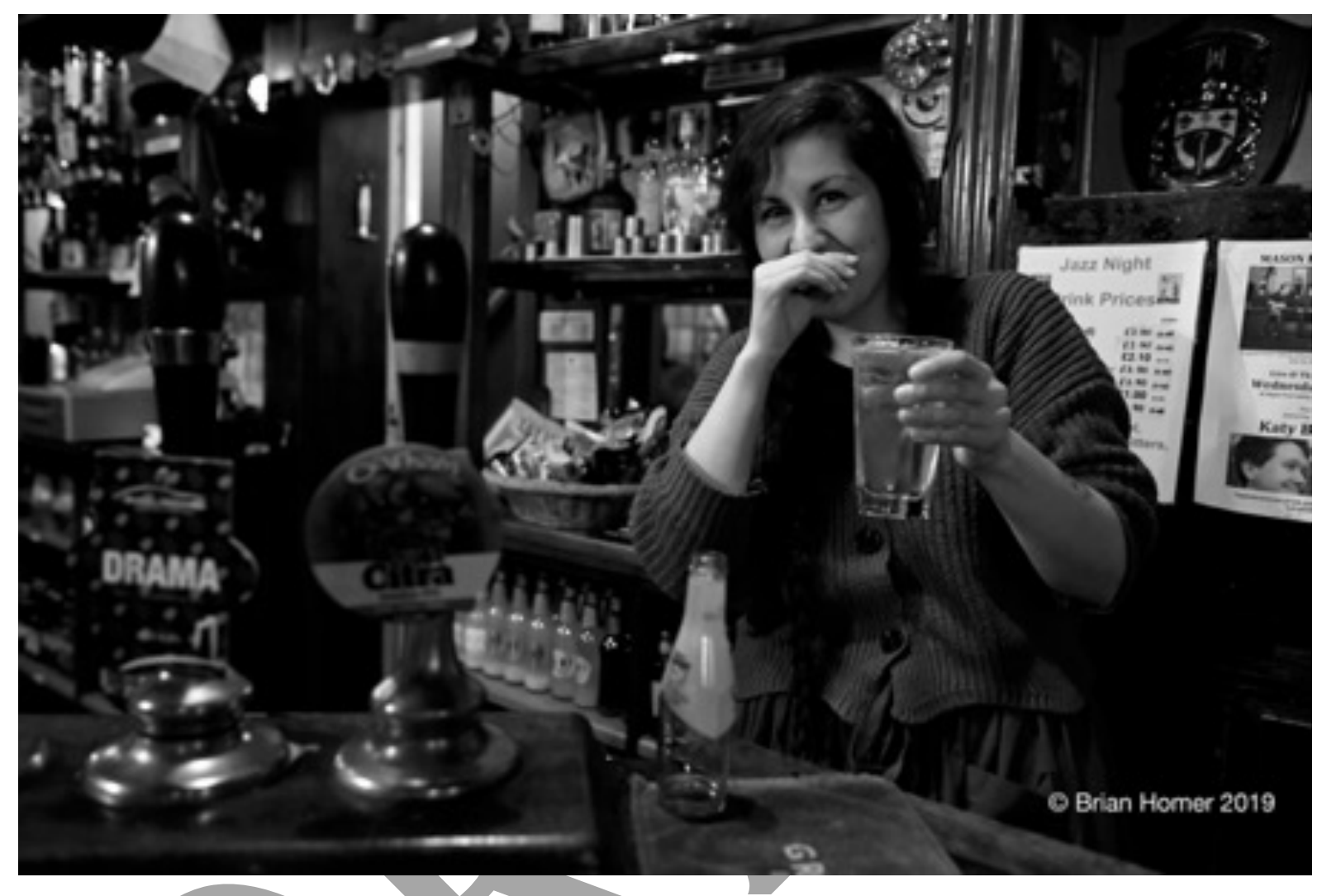

Figure 1 - Alicia at the Spotted Dog, 104 Warwick Street, Birmingham

"When I did move out (of home after college) I was mainly making an income from the Spotted Dog and another pub in the Black Country at the museum there. So I was dressed as a Victorian pulling pints there... at one point I was doing, a couple of years ago, I'd be working at the museum, I'd come back and teach a few students and then I'd go to the Spotted Dog and do a shift and I don't know how I did that now because I'm tired after a day's teaching" (GardenerTrejo 2019). ${ }^{15}$

BH: Alicia pulling pints at the Spotted Dog on a Tuesday jazz night. There were two photographic challenges for this shot, first the very poor light and second getting a natural feel given that it was a set up situation with limited time. Although careful use of flash can mitigate low light I prefer to shoot available light for a less formal look. Here I used a $28 \mathrm{~mm}$ f1.8 prime lens set at $f 2.8$ with a slow $1 / 50^{\text {th }}$ second shutter speed at ISO 3200. Shooting at a

\footnotetext{
${ }^{14}$ With the support of Jazzlines THSH, the ensemble will be morphing into a quintet featuring trumpeter Aaron Diaz, pianist Andrew Woodhead, cellist Emma Capp and violinist/vocalist Faith Brackenbury. The band will be performing brand new music that incapsulates Bobtail's quintessential quirky character and rich textures.

${ }^{15}$ Gardener-Trejo with Cravinho (14'55" - 16'11").
} 
slow shutter speed was aided by the built in stabilisation in my Nikon Z6. By chatting to Alicia about sessions at the pub I was able to get a more spontaneous moment which matched her quote better than a more formal portrait. ${ }^{16}$

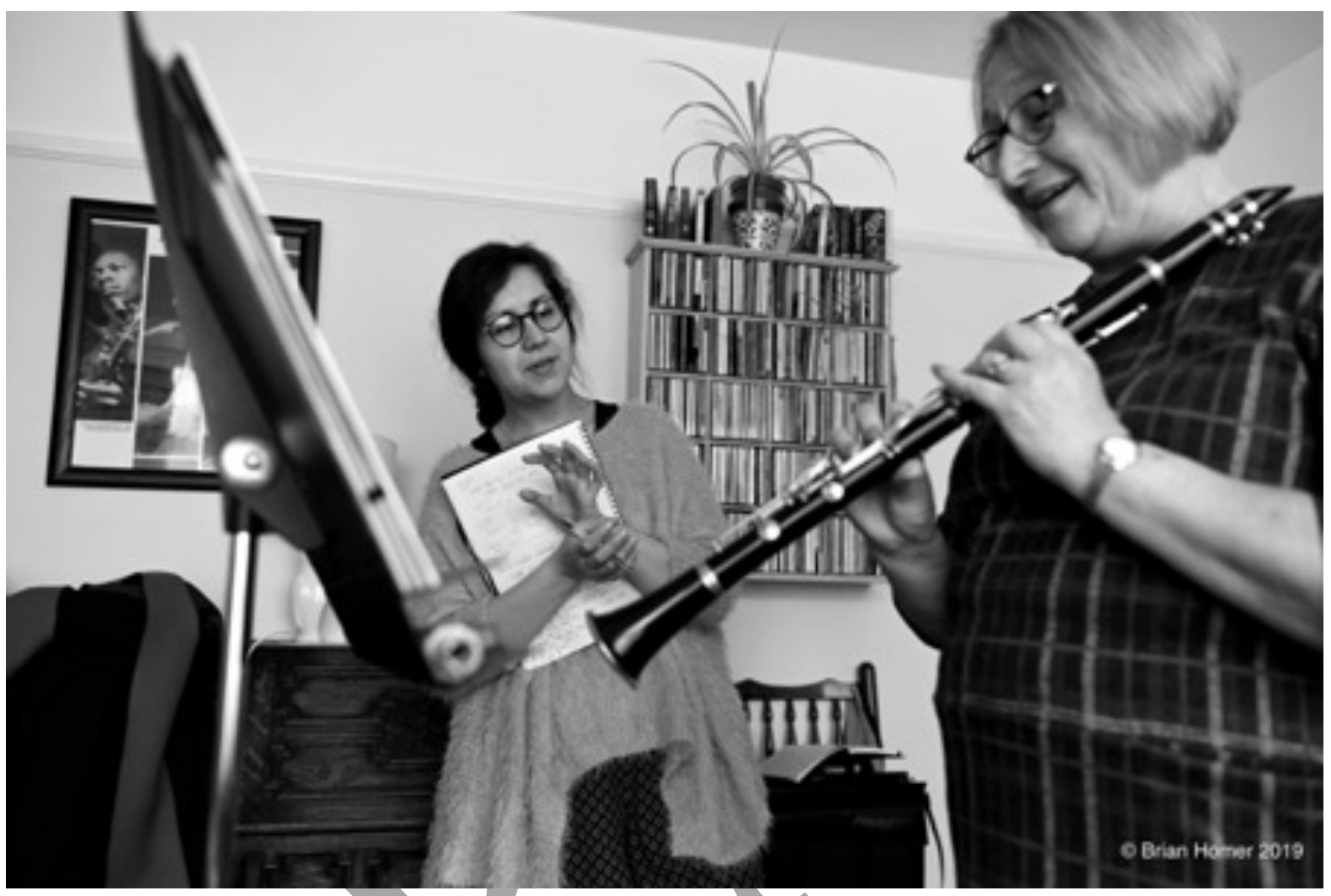

Figure 2 - Alicia teaching at her place, Birmingham

"So currently it's mainly teaching [that] is probably how I make most of my income, gigs, [and] function gigs would come next and then creative gigs occasionally you get paid for and Spotted Dog on the jazz nights. That's dwindling a little bit I'm probably there two or three times a month, not every week. So, I've managed to get that balance now" (Gardener-Trejo 2019). ${ }^{17}$

BH: Teaching a student at home. Domestic rooms can be challenging as backgrounds can be confused, space at a premium and window lighting means certain angles are better. The $28 \mathrm{~mm}$ lens is great for this type of situation and is one of the classic documentary focal lengths allowing you to include plenty of context but get in close while not getting excessive distortion. Daylight allowed use of ISO800 at 1/200 second f2.8. It was a real composition bonus to get the Coltrane poster into the shot.

\footnotetext{
${ }^{16}$ Brian Homer comments related to each photograph are written in italic and identified with his initials BH.

${ }^{17}$ Gardener-Trejo with Cravinho (39'48' - 40'25').
} 


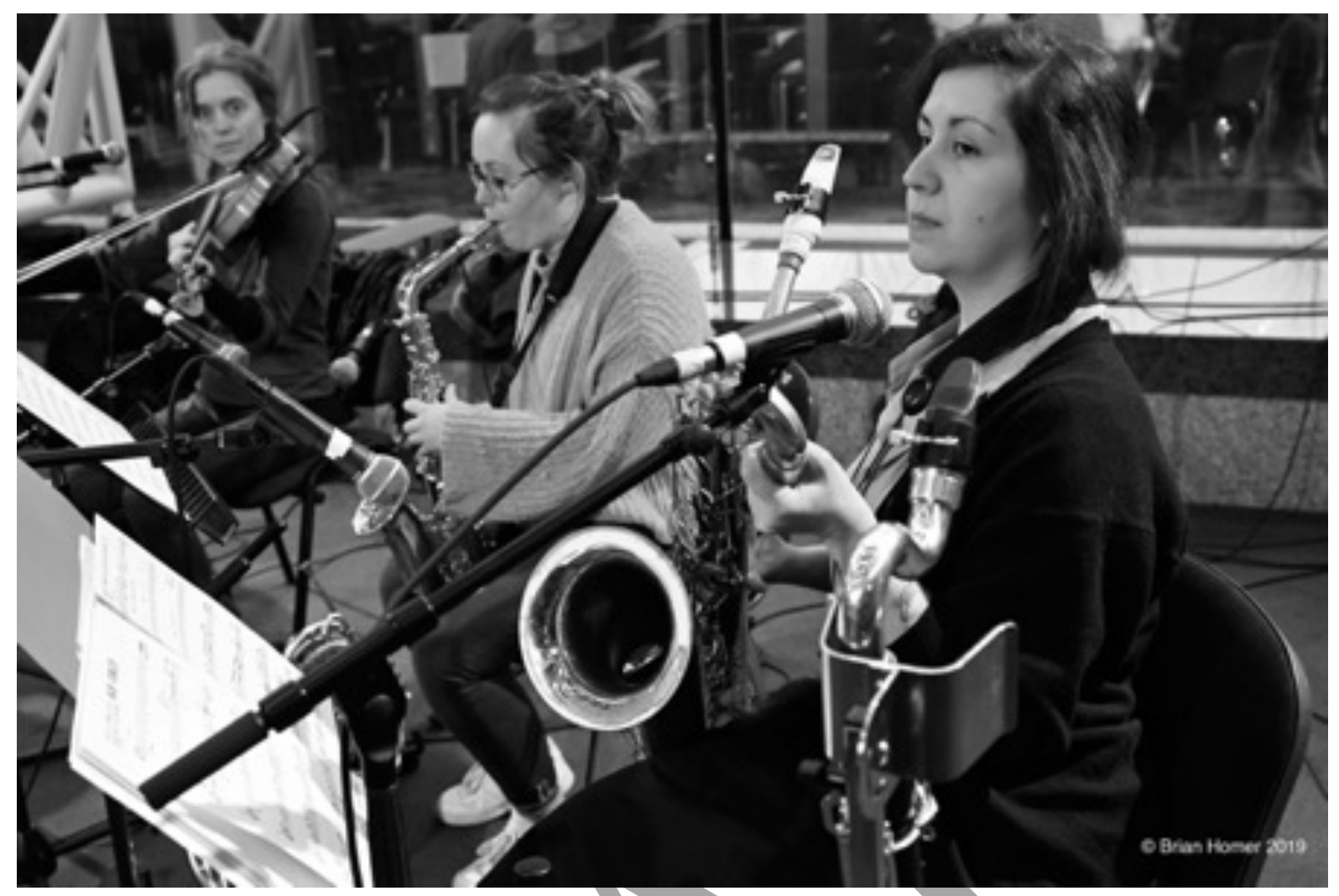

Figure 3 - Alicia at Symphony Hall, Birmingham

"I've got a large ensemble of eleven people so if I want to pay people properly that's going to have to come out of funding or my own pocket which ends up being very expensive. But you don't want to keep asking people to do things for free. A lot of the time they'll say we'll do it anyway and I'm on the other end of things where there's bands that I enjoy doing that don't necessarily pay but I would do them just because I love them anyway... as a band leader you do feel bad for not paying people" (Gardener-Trejo 2019). ${ }^{18}$

BH: Alicia leading a sound check for one of her ensembles before a gig at a Jazzlines Rush Hour Blues session at the Symphony Hall foyer. For most of the project I wanted to look behind the usual gig photograph but while this is a performance situation, because it is a sound check, I had much more freedom to get close and into positions where it would be distracting during the actual gig. The light was pretty good so I was able to shoot with a 24$70 \mathrm{f} 4$ zoom lens (set to $40 \mathrm{~mm}$ f5.6 ISO3200) to give flexibility in framing. I was trying to give an impression of Alicia's leadership and focus and also some interaction with band members.

\section{Participant 2. Chris Young}

\footnotetext{
${ }^{18}$ Gardener-Trejo with Cravinho (37'20”' - 38'00”).
} 
Chris Young is a saxophonist and composer based in Birmingham. Graduating from Royal Birmingham Conservatoire with first-class honours, over the last decade, Chris has already made his mark on the local scene. Chris curated various regular jazz gigs around the city including Churchill's, Jazz at the Brown Lion and Jazz at the Jewellers Arms, Cognitive Jazz Therapy and currently promotes the nationally acclaimed Jazz at the Spotted Dog, alongside David Ferris. Additionally, Chris also works closely with the Jazzlines Education Programme and leads two ensembles that performed at Sid Peacock's Surge Festival and the Symphony Hall Foyer. As a performer, Chris's projects include, Orbits, JACKED, Chris Young Sextet, Hans Koller/Chris Young Quartet, as well recording and touring with Ben Lee Quintet, Hansu Tori, David Ferris Septet, Reworkestra, Birmingham Jazz Orchestra, Acid Body, Antelope, A Moveable Feast, Steve Troman's 'Howl' and Blue Pearl.

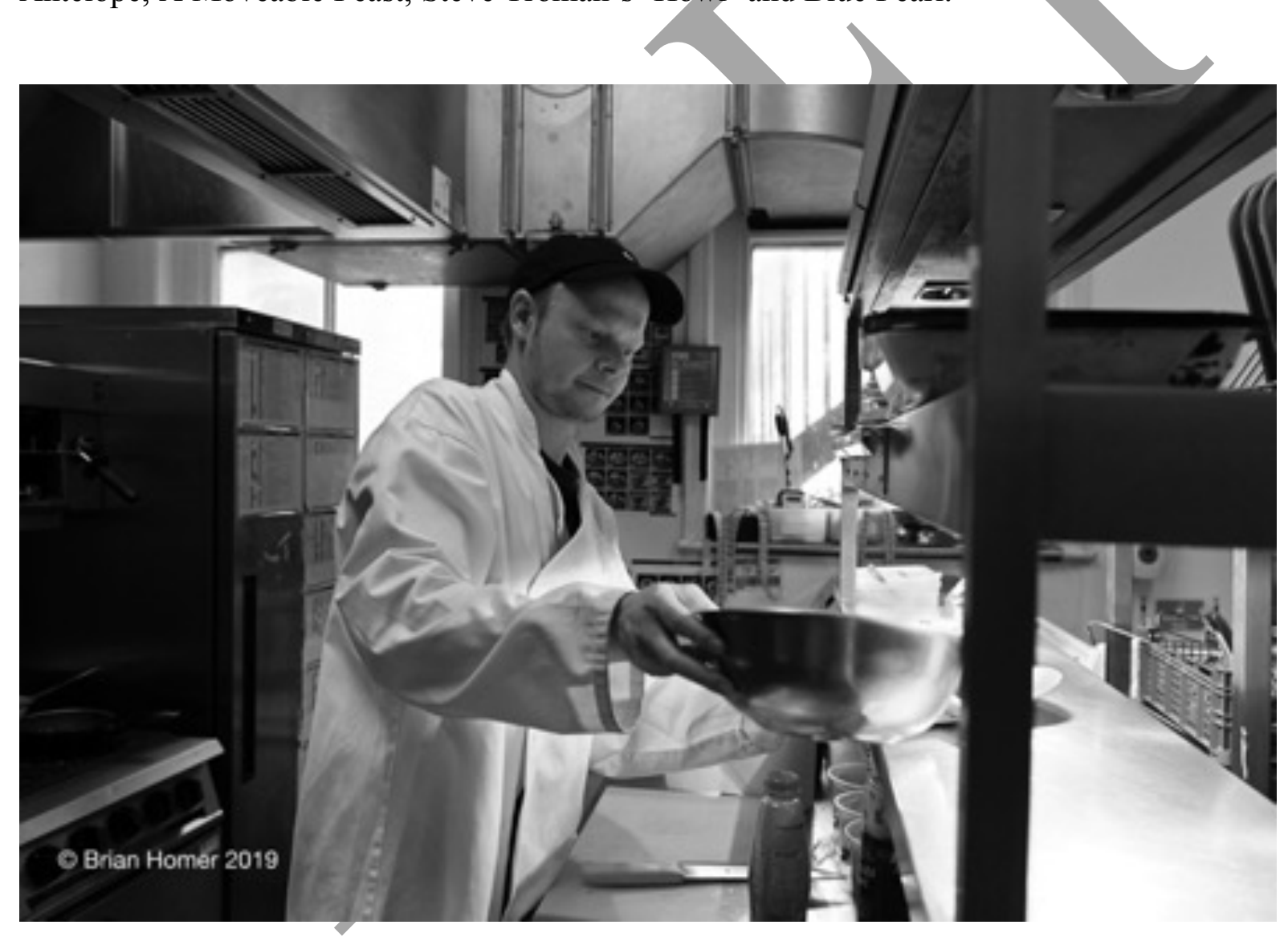

Figure 4 - Chris at The Shakespeare, Summer Row, Birmingham

"I kept the boarding school and the Jazzlines stuff and I've got some private students. The other school stuff I've started to find a bit difficult... you get home and you want to write or practice and you don't want to because you're knackered and it's stressful... I like the pub and knew the manager well, she was struggling for a chef so I said I'll give it a go... that was about a year ago and I'm still there now and I'm still there now and I'm really, really enjoying it" (Young 2018). ${ }^{19}$

${ }^{19}$ Young with Cravinho (20’20”-21'50”). 
BH: As soon as I heard that Chris was cooking I knew I wanted to get this shot to illuminate what musicians do to make a living and keep the music alive. Permission from the brewery took a while and we had to choose a comparatively quiet time so I didn't get in the way. It was another location with limited room and potentially confusing backgrounds, reflections and backlighting from the windows. Again the $28 \mathrm{~mm}$ lens proved ideal this time $1 / 200^{\text {th }}$ second at f4.5 ISO1600 allowing me to get some interesting perspective and angles that adds to the focus on Chris.

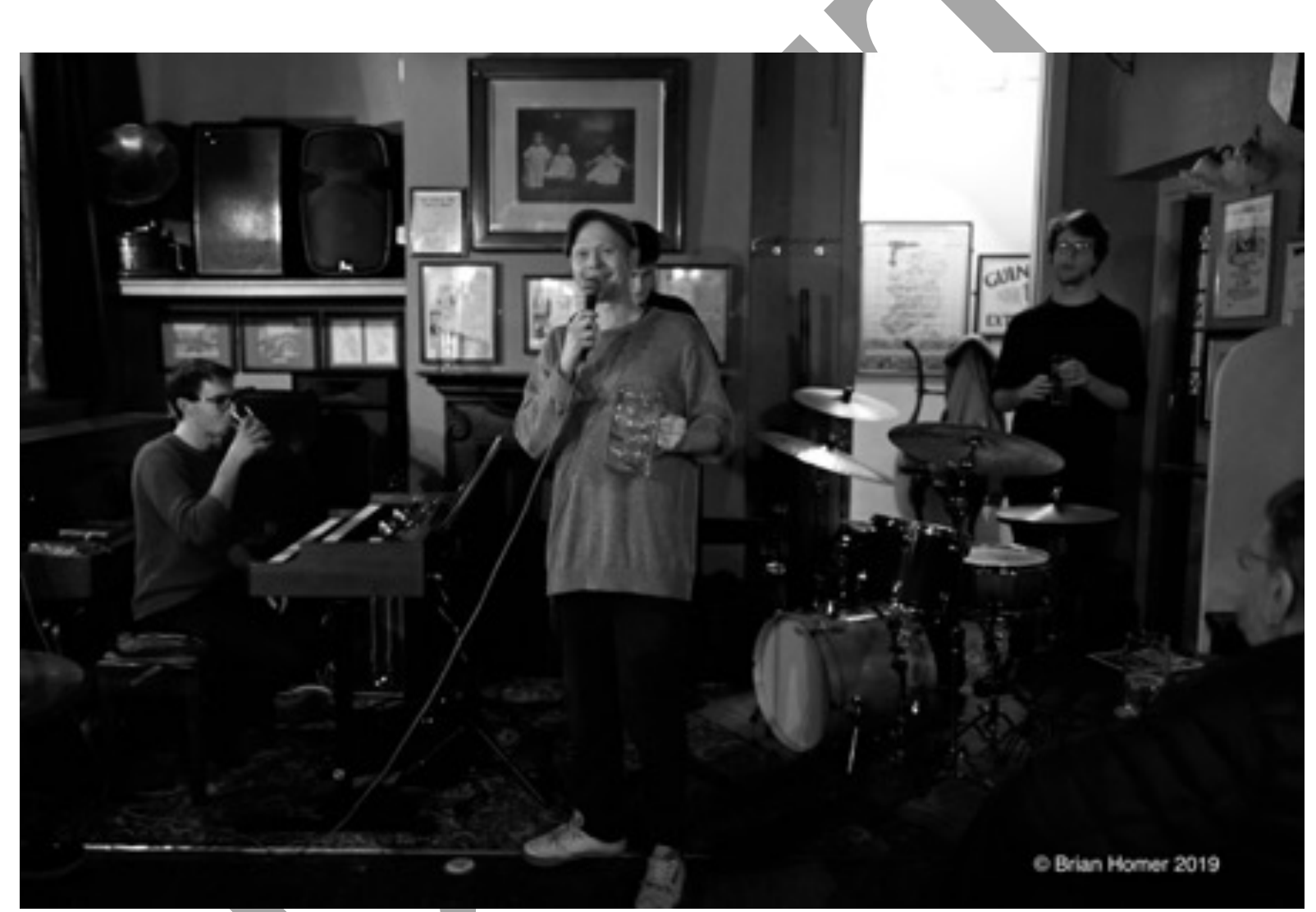

Figure 5-Chris at the Spotted Dog, 104 Warwick Street, Birmingham

"I started from scratch the night at Cogs Bar which ran for a couple of years, trying as much as I can to repay the people that had given me gigs in the first place, supporting students and people who had helped us I wanted to give that back. There's amazing things happening in London and around the country and the international acts but there is lot to be said about what actually happens in Birmingham. Occasionally that can get overlooked. And now I'm running this night with Dave (Ferris) at the Dog" (Young 2018). ${ }^{20}$

BH: Not just a musician but a promoter, a teacher, a cook and more. Shot at the Spotted Dog with Chris introducing the David Ferris Trio, led by David on organ, and featuring Ben Lee

\footnotetext{
${ }^{20}$ Ibid. (27'08"- 27'42"). At the time of the interview David Ferris was still co-running Jazz at the Spotted Dog. Since then drummer Nathan England Jones has taken his place.
} 
(hidden), on guitar, and William Weir, on drums. Chris is holding the jug for donations which references his other quote under the picture of him work in a bar. The light in the Spotted Dog is notorious amongst photographers for being particularly low - this makes shooting there very difficult. The $28 \mathrm{~mm}$ lens came into its own again set almost wide open at f2.0 and I had to go to ISO6400 to get a reasonable shutter speed of $1 / 170^{\text {th }}$ second. Unlike many jazz shots when the focus is on one musician I wanted to reflect that Chris was introducing the band in his promoter role and not playing. The high ISO does result in more 'noise' but in black and white the noise resembles film grain and adds rather than distracts from the feel of the shot.

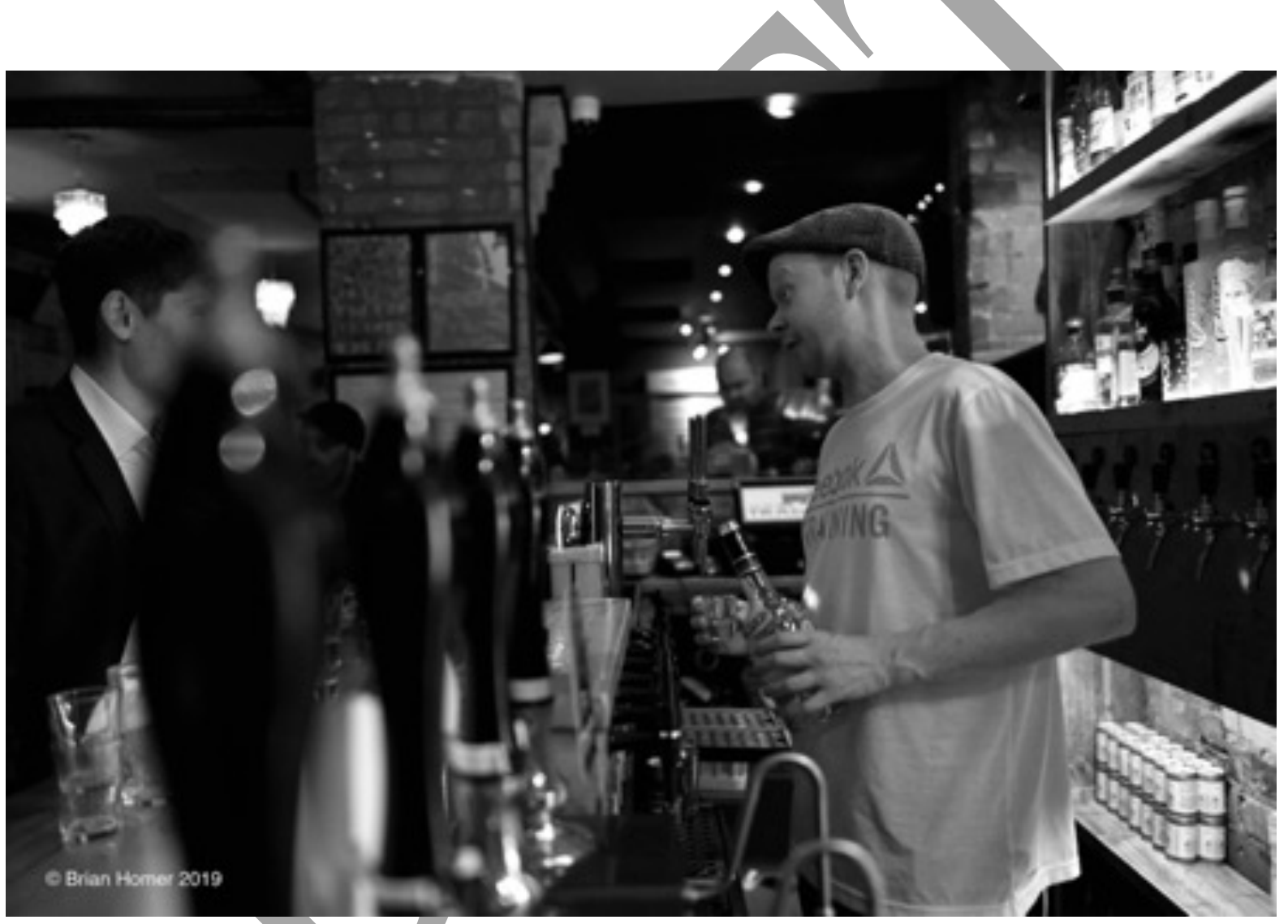

Figure 6 -Chris at the 1000 Trades, 16 Frederick Street, Birmingham

"There is a big issue with money, ticketing, and how we get funded, how people get paid basically. It's difficult and people look at it differently... There's different ways of providing that but ultimately as a working musician I don't know exactly what I'm going to receive from each place but there's not a huge amount of difference. I think there is a culture, and this is separate from the scene I guess, I don't think people for some reason in Birmingham expect to pay to come in. It's the price of a pint or a couple of pints but that is seen as almost outrageous to give your money away for that. Whereas you play in London, or you play in Manchester or you play Liverpool or Leeds, most places you go elsewhere you pay as you go in" (Young 2018). ${ }^{21}$

${ }^{21}$ Young with Cravinho (29'55" - 31'49”). 
BH: Chris behind the bar at 1000 Trades in the Jewellery Quarter in Birmingham which is also his local and where Birmingham Jazz run their gigs usually on a Friday night. Another pub, another challenging level of light. ISO3200 with the trusty $28 \mathrm{~mm}$ lens wide open at f1.8 to get $1 / 200^{\text {th }}$ second shutter speed. Unlike the shot of Alicia in similar circumstances I didn't engage with Chris but let him get on with working and waited for interaction to happen. I deliberately chose to either hide the customers or have them out of focus to avoid permission issues.

\section{Participant 3. David Austin Grey}

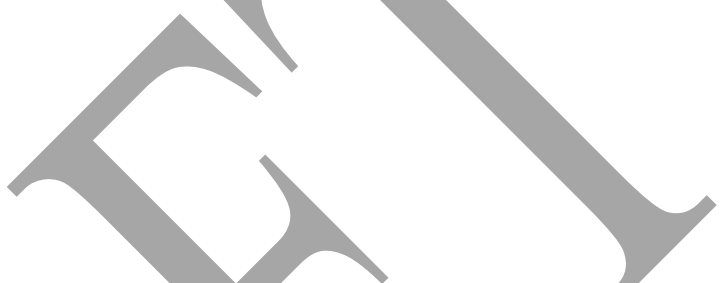

David Austin Grey is a pianist, composer and educator working across multiple musical disciplines in UK and internationally, including residencies in Brazil and South Asia. As a graduate of the University of Birmingham and Royal Birmingham Conservatoire, David has worked with such well-respected artists, and institutions, such as Courtney Pine, Eliza Shaddad, Soweto Kinch, Michael League, Black Voices and Snarky Puppy, and the Birmingham Royal Ballet, and the British Council. He has also supported GRAMMYwinning artists Marcus Miller, Terri-Lyne Carrington and Snarky Puppy, and has appeared at numerous venues and festivals across the UK. ${ }^{22}$ In 2018 was awarded a place on Sound and Music's national 'New Voices' programme. ${ }^{23}$ When he is not making music, David concentrates his energies on photography and martial arts, which has been practiced various martial disciplines for over fifteen years and teaches Taekwondo in his home city of Birmingham. $^{24}$

\footnotetext{
${ }^{22}$ Including, Cheltenham Jazz Festival, The Royal Albert Hall, Mostly Jazz Funk \& Soul Festival, Harmonic Festival, LUME Festival, Symphony Hall, Birmingham Hippodrome, Manchester International Jazz Festival, Birmingham Town Hall, The Flyover Show, BASS Festival, Arts Fest UK, and Glasgow International Jazz Festival.

${ }^{23}$ David Austin Grey's most long standing group 'Hansu-Tori' has received national press and radio play on the BBC Radio 3, Jazz FM, BBC Introducing, BBC WM, BBC Radio Scotland, and Jazzwise magazine.

${ }^{24}$ For further details on artist's webpage at http://www.davidaustingrey.com/.
} 


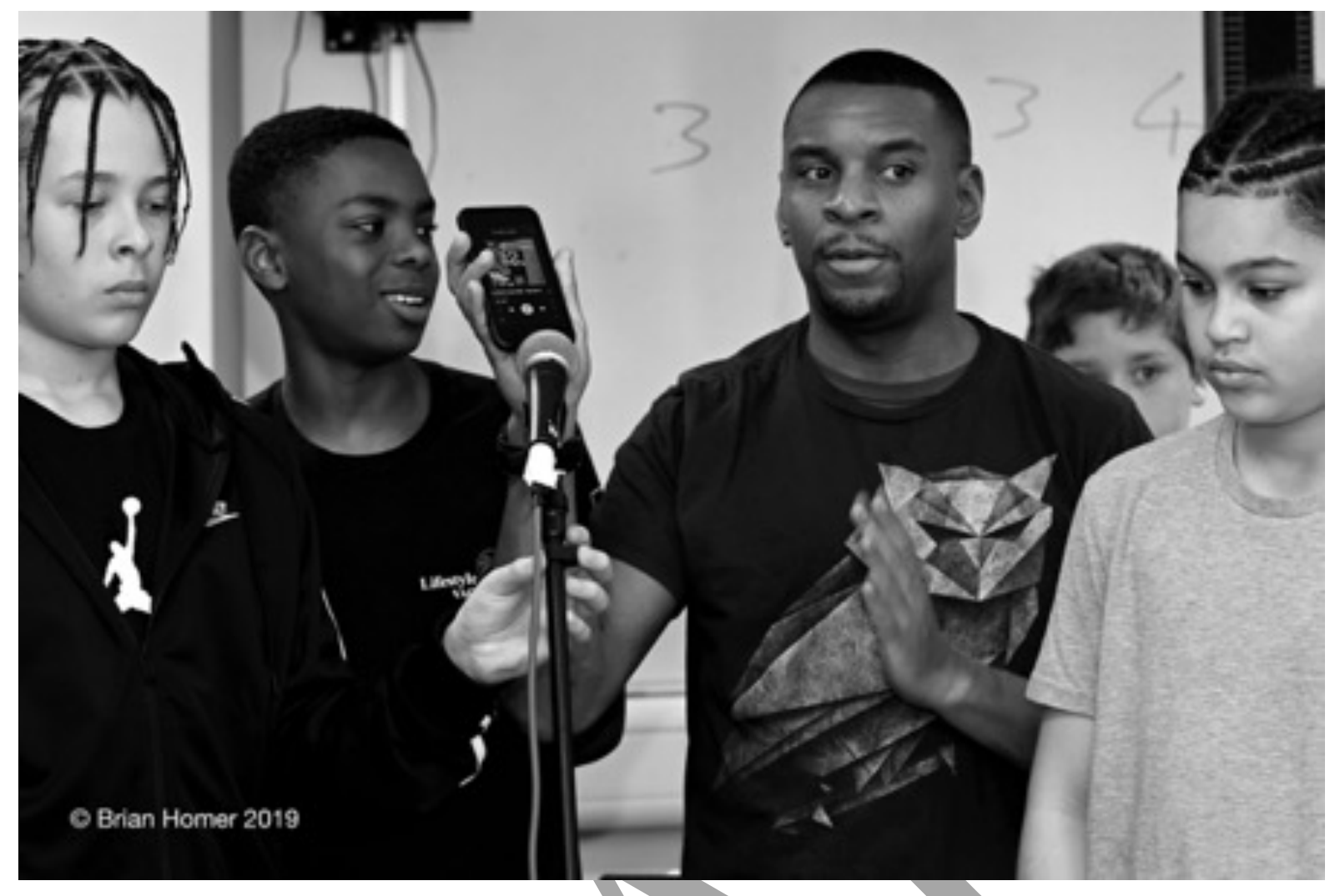

Figure 7 - David with the SoundLab project, Coventry

"I consider myself as a musician who plays jazz amongst other things...so within music, aside from the playing, I would say primarily now I see myself as a composer first and then a performer second. But I also do a lot of education work. So I do a lot of workshop teaching for THSH and for the Conservatoire, I work on a programme called SoundLab which is based in Coventry - like an outreach programme of musical education. Which is not specifically jazzrelated at all" (Grey 2019). ${ }^{25}$

BH: David with young participants at the SoundLab project in Coventry on a Saturday morning. The large windows in the classroom allowed ISO800 with the $85 \mathrm{~mm}$ lens set to 55.0 (to ensure all the faces were in reasonable focus) at 1/125th second. I used the $85 \mathrm{~mm}$ lens because although large the classroom was actually packed with students and tutors so to avoid being a distraction in the middle of the room I had to position myself across the other side of the room. David was playing back a demonstration track and I wanted to get some interaction but also a feel of him leading and students listening. The almost painterly composition is to my eyes pleasing - it can be hard to get groups of this size composed successfully - it was made easier by their natural arrangement and the fact that I was across the room out of their eyeline so they didn't notice me.

\footnotetext{
${ }^{25}$ Grey with Cravinho (13'20" - 14'35”).
} 


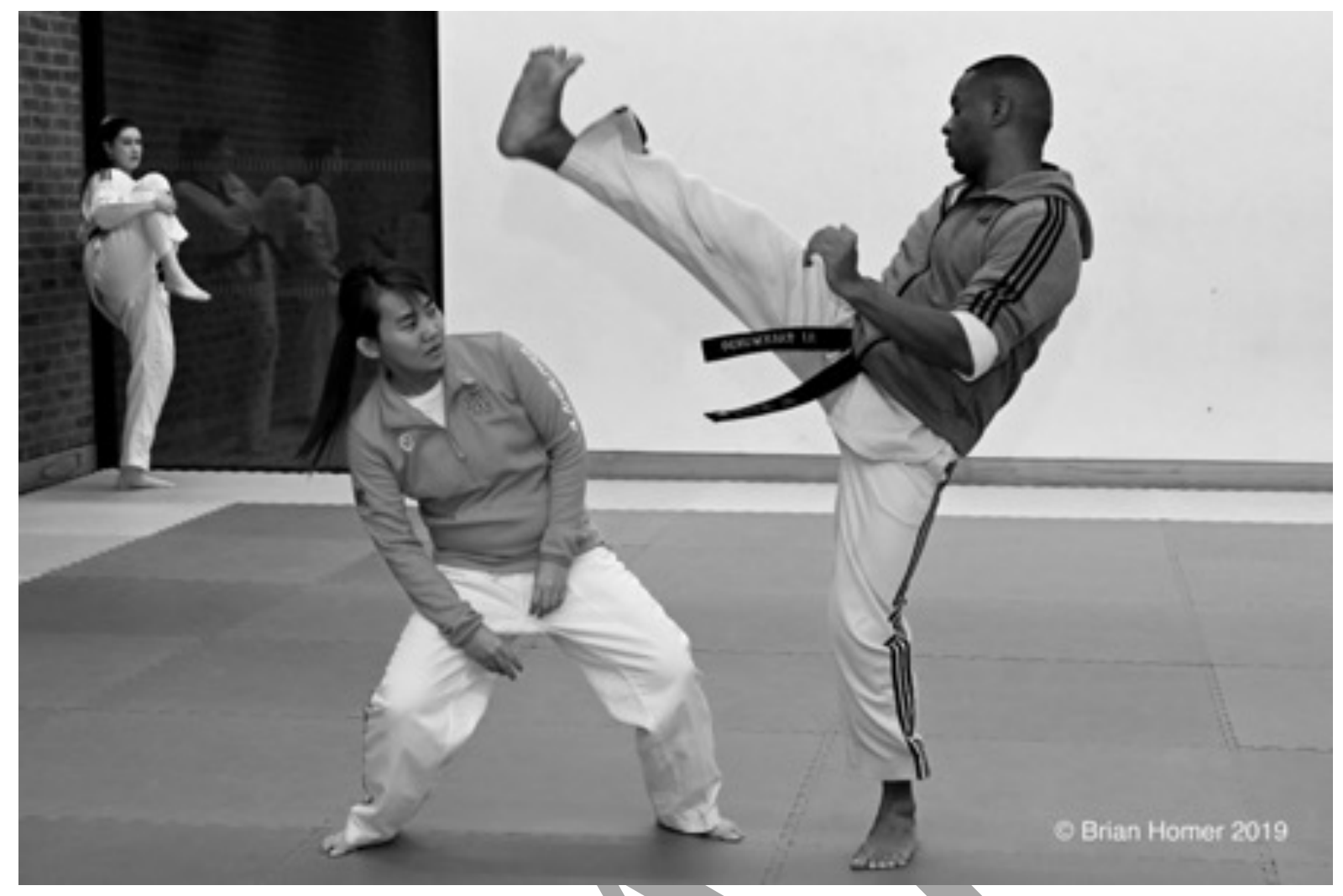

Figure 8 - David leading a Taekwondo class at the Birmingham University

"I also do some sports coaching as well, so I coach Taekwondo club at the University [of] Birmingham, I've been doing that for a long while actually, about 13-14 years. I'm always trying to balance the two... the teaching was a way for me to support myself by doing something that I enjoy as well, while still allowing me time to dedicate to the development of the music. But at the same time it is a part of my identity as well, a part of my life. The martial arts feeds in to the music and they are definitely interlinked... Currently music is something that I am and martial arts is more something that I do, I'm more invested in musical exploration." (Gray 2019). ${ }^{26}$

BH: This shot of David leading a Taekwondo class at the University of Birmingham was another one I knew had to get to go with the interview. So it was shot during a class but I tried to just let the images happen and to get a relaxed feel of not being set up. Reasonable electric light allowed use of the 24-70 f4 lens for the ability to quickly change focal length to suit as the action was fast moving. It was almost wide open at f4.5, ISO 3200 allowing 1/200 th second with lens at the traditional standard setting of $50 \mathrm{~mm}$. Although I was concentrating on David's body shape and interaction with the student I was also aware of and attracted to the student in the background stretching and her reflections and with the way the white walls,

${ }^{26}$ Grey with Cravinho (14’35”-15’12”) and (38’57”-40’05”). 
dark window and floor split the composition into distinct areas with the main student bridging linking the areas.

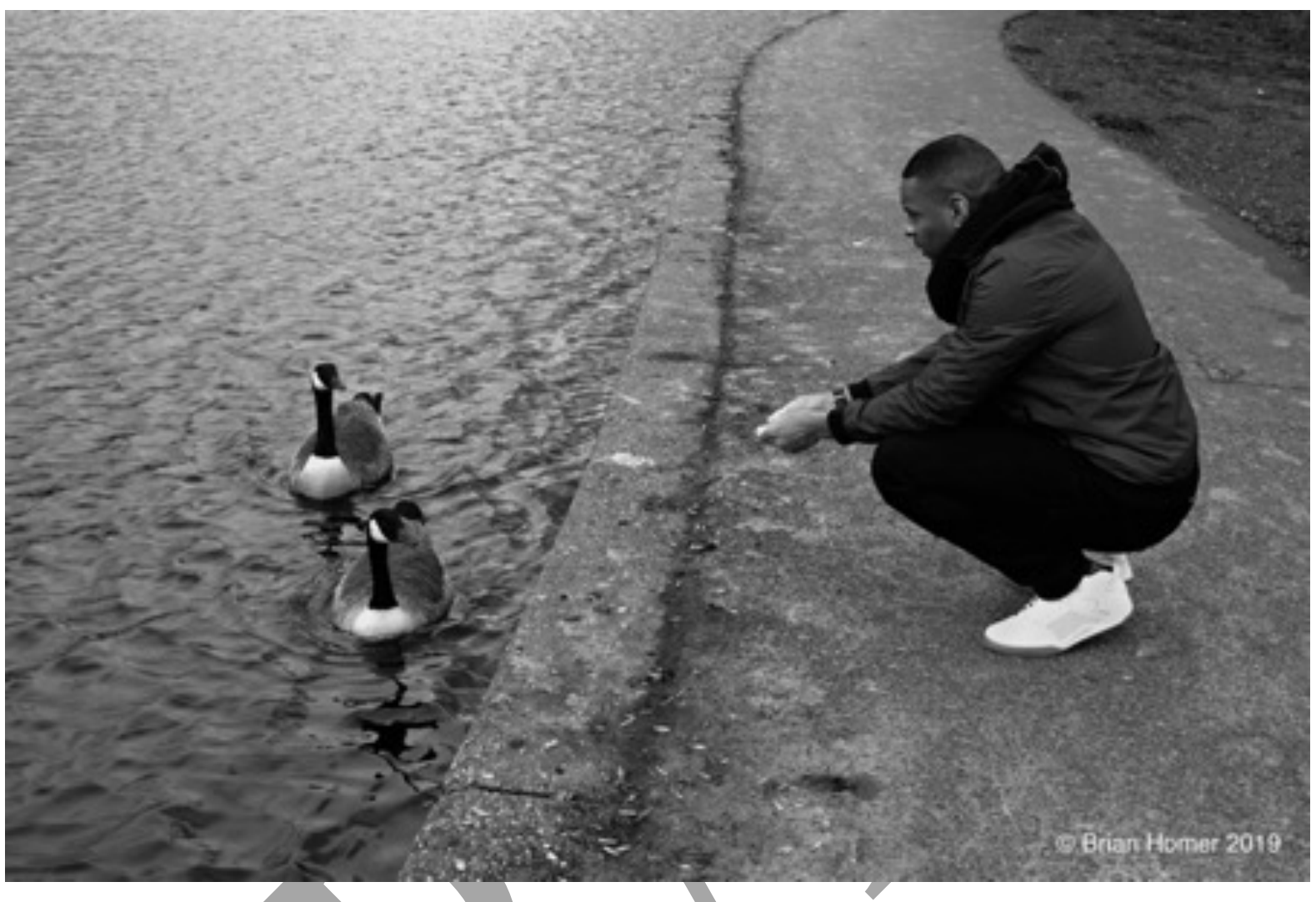

Figure 9 - David at the Valley Pool, Bournville, Birmingham

"For composers and musicians, for myself anyway, I want to do things which are gonna push me forwards, I want to do things that are more challenging and stretch my approach to writing music, my approach to presenting and playing music. So, I am doing something that is challenging and therefore more interesting to me...but there aren't necessarily venues and promoters who are willing to take that same risk." (Grey 2019). ${ }^{27}$

BH: David is working on a new piece based on the migration of birds so we shot this at a pool that he often drives by. Although there were plenty of birds at the location it was really challenging to get an opportunity to put then in an appropriate and interesting relationship with David. Being outside meant ISO400 was possible as was the use of the 24-70 f4 zoomwhich by coincidence was set to $28 \mathrm{~mm} f 6.3$ and a fast shutter speed to freeze any action of $1 / 400^{\text {th }}$ second. We tried a number of things but this shot seemed to reflect both the subject of David's composition, his thoughtful approach and with some interaction with the birds.

${ }^{27}$ Ibid. $(34.38-35.27)$. 


\section{Participant 4. Joey Walter}

Joey Walter, a saxophonist, graduated from Birmingham Conservatoire in 2009, and began her career as a musician in pit orchestras around the Midlands. Being brought up in a house buzzing with jazz she went on to form the jazz saxophone quartet Me \& 3 and has played with the Walsall Jazz Orchestra for many years. After her time at music college Joey studied woodwind repair at Merton College, London. She now works as a woodwind repair specialist from her home the Midlands. With the arrival of her (now 3 year old) daughter Imogen, Joey set up an organisation, Project Create, hosting book clubs for parents and providing a pop up crèche to accompany performances in theatres. In recent months Joey has become involved in acting, taking lead roles with a drama club based in Birmingham. With acting as another string to her bow, Joey intends to try her hand as an actor musician work along with getting her children's book Jazz In The Jungle published and her new play Raising The Steaks onto the stage.

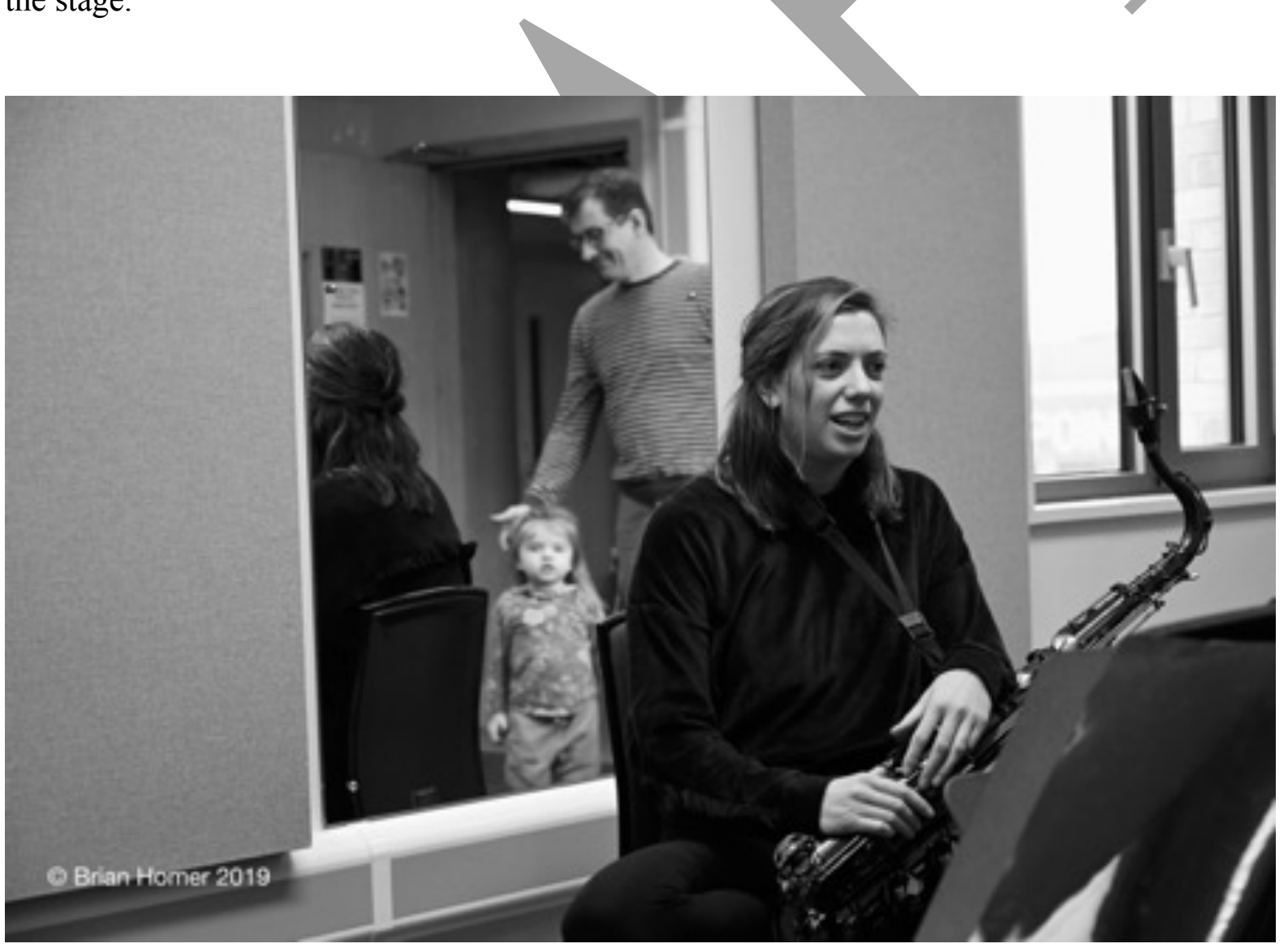

Figure 10 -Joey’s Me\&3 saxophone quartet rehearsal, Birmingham

"Because sometimes it's a nightmare, sometimes it's really stressful, especially if your partner is also a musician, because I always joke that Ben gets the real gigs that pay really well. So, if 
I have got a run of a show he can get offered one gig that earns more than mine all week. So naturally, I then have to dep my gig out" (Walter 2019). ${ }^{28}$

BH: I didn't plan this shot it just happened while photographing a rehearsal of Joey's Me\&3 saxophone quartet but her comment was in my mind so as soon as I saw it, I made sure I caught it. Her partner Ben Markland a professional bass and sax player is in the shot with Imogen their daughter. The room at Royal Birmingham Conservatoire had good light but was small with a lot of space taken up with a grand piano so ISO was I60Q and I again used the 24-70 f4 zoom to allow plenty of framing options as I manoeuvred around the players.

The lens was wide open at f4 shutter speed was $1 / 160^{\text {th }}$ second and focal length $58 \mathrm{~mm}-$ near the standard of $50 \mathrm{~mm}$.

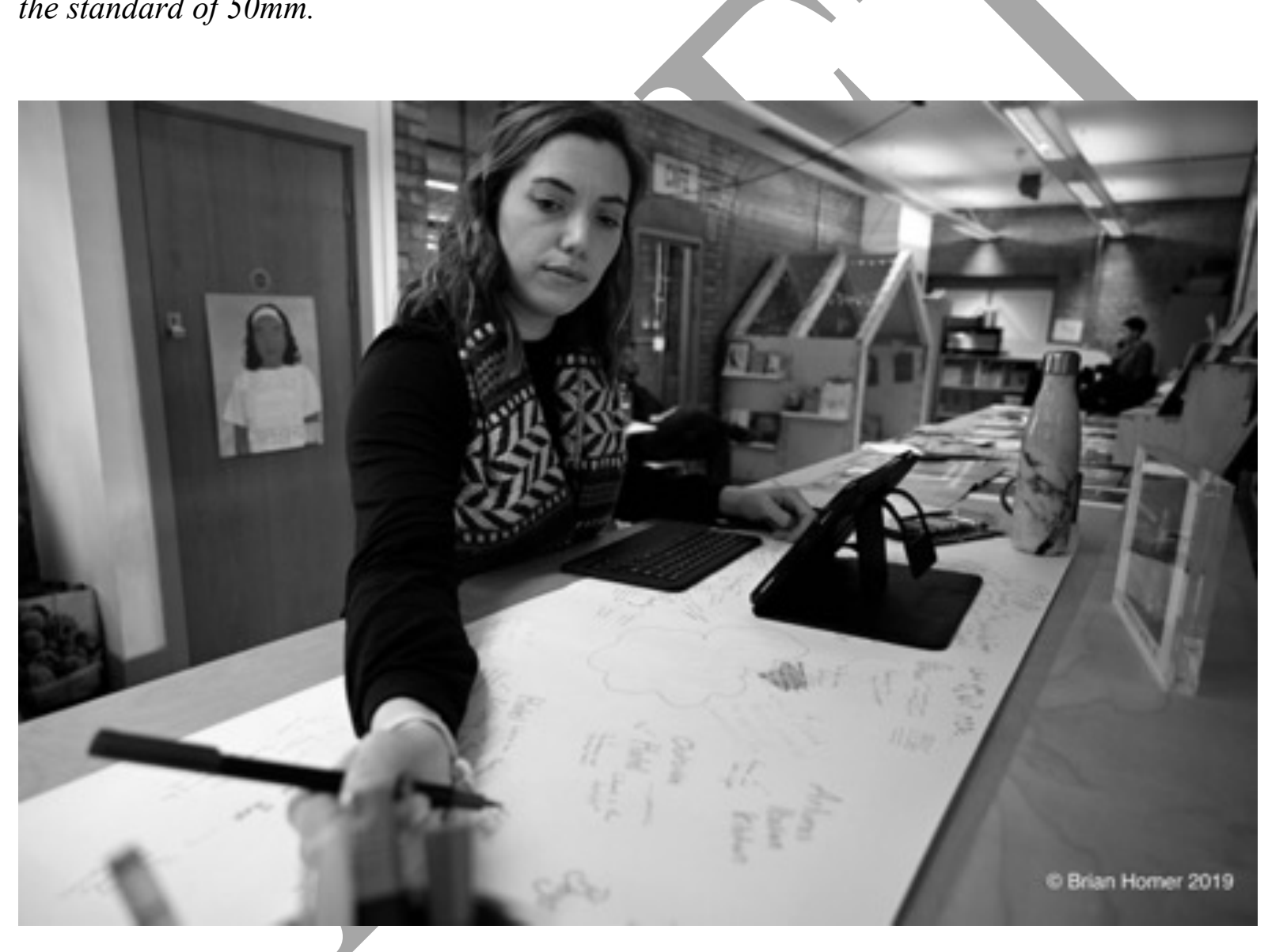

Figure 11 -Joey working at the Impact Hub, Birmingham

"It's just finding the time and the money....and with me it's the child care as well. I've been working on a project at the moment called Project Create Midlands and that's trying to look after parents in the Creative Arts industry. The end goal is to have a venue where you can hire a studio if you need to practice or you want to run a rehearsal but it will also have a crèche so you know your child is safe having fun" (Walter 2019). ${ }^{29}$

\footnotetext{
${ }^{28}$ Walter with Cravinho (48'38' - 49'01').

${ }^{29}$ Walter with Cravinho (44'27' - 45'05').
} 
BH: Joey working at the Impact Hub in Birmingham where she regularly goes to develop her writing and other projects. While there Imogen her daughter plays in the crèche. Light was OK so it's ISO1600 and the 24-70 f4 zoom is set to $24 \mathrm{~mm}$ and is wide open at f4 to throw the background out of focus and shutter speed $1 / 160^{\text {th }}$ second. I chose to go to $24 \mathrm{~mm}$ to get the perspective to accentuate her arm and hand and the link with the work on the paper. The picture on the door in the background and the figure in the right background, together with the increased perspective encourage the eye around the composition and locate Joey in the context of the Hub.

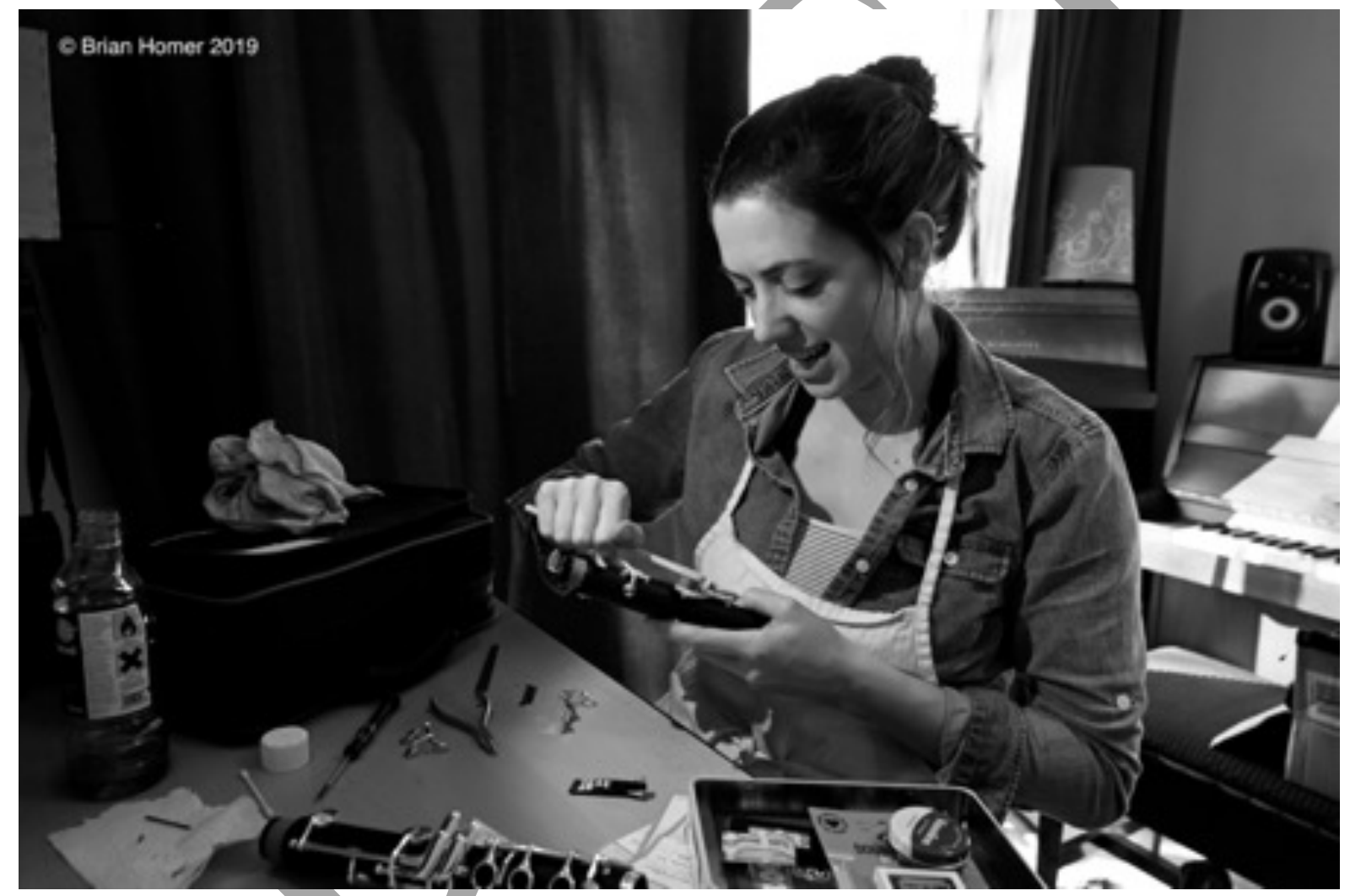

Figure 12 -Joey repairing woodwind instruments, Walsall

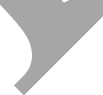

"I also repair woodwind instruments at home, because I can't do much at the moment with Imogen because she's only two and a half. So, I repair for a few of the companies around the West Midlands, it's not too much work, it comes and goes." (Walter 2019). ${ }^{30}$

BH: The challenge with getting some of the shots of Joey was that different parts of her living room are the locations for teaching, rehearsing and instrument repair. This reflects how

${ }^{30}$ Ibid. $\left(27^{\prime} 03^{\prime \prime}-27^{\prime} 20^{\prime \prime}\right)$. 
musicians have to be flexible in the things they do to make a living. The place where she does the instrument repair is not well lit and although there is a mirror in front of her work bench the main electric light and window light are behind her. On this occasion the lighting was augmented by an out of shot table lamp. Even so it was at ISO3200 but I was able to use the 24-70 f4 zoom at f5.6 and 1/200 th second. This allowed be to frame in a tight place with my back pushed up against a door frame and wall. As it happened my go to $28 \mathrm{~mm}$ setting gave me the right relationship between Joey and her repair tools with some moderate perspective and a hint of teaching with the piano in the background.

\section{Ruth Angell ${ }^{31}$}

Ruth is a violinist, guitar player, composer, lyricist and vocalist. Her musical journey began with an eighth size violin and Piccadilly Circus. She moved through the spheres of school choir and orchestra, area string orchestra, national youth training choir, county youth orchestra and then to the Birmingham Conservatoire where she gained a BMus in Music Composition. There she discovered that folk and acoustic music was where her heart lay. She plays in the Peacock Angell band with her partner Sid Peacock with whom she collaborates on a range of projects including Sid's eclectic large ensemble SURGE. She has worked with Ashley Hutchings, including the Rainbow Chasers band and has also played with Rufus Wainwright. She is a member of folk quartet The Froe and regularly gigs in other formats including a duo with Becky Mills.

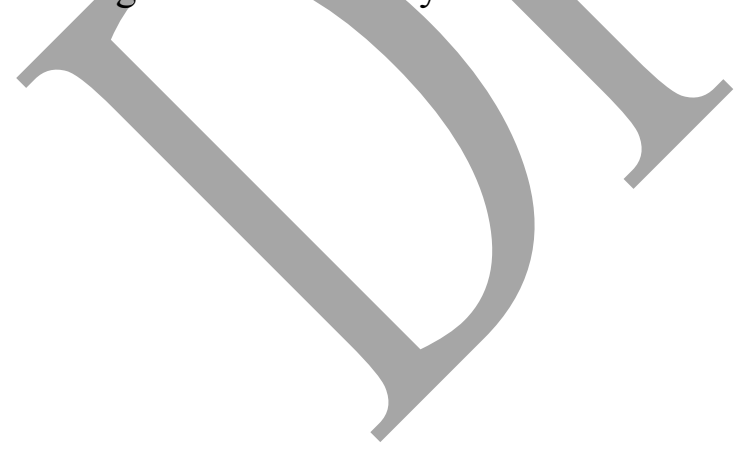

\footnotetext{
${ }^{31}$ For further details on Ruth Angell projects, see the artist's webpage at http://www.ruthangell.com/about/
} 


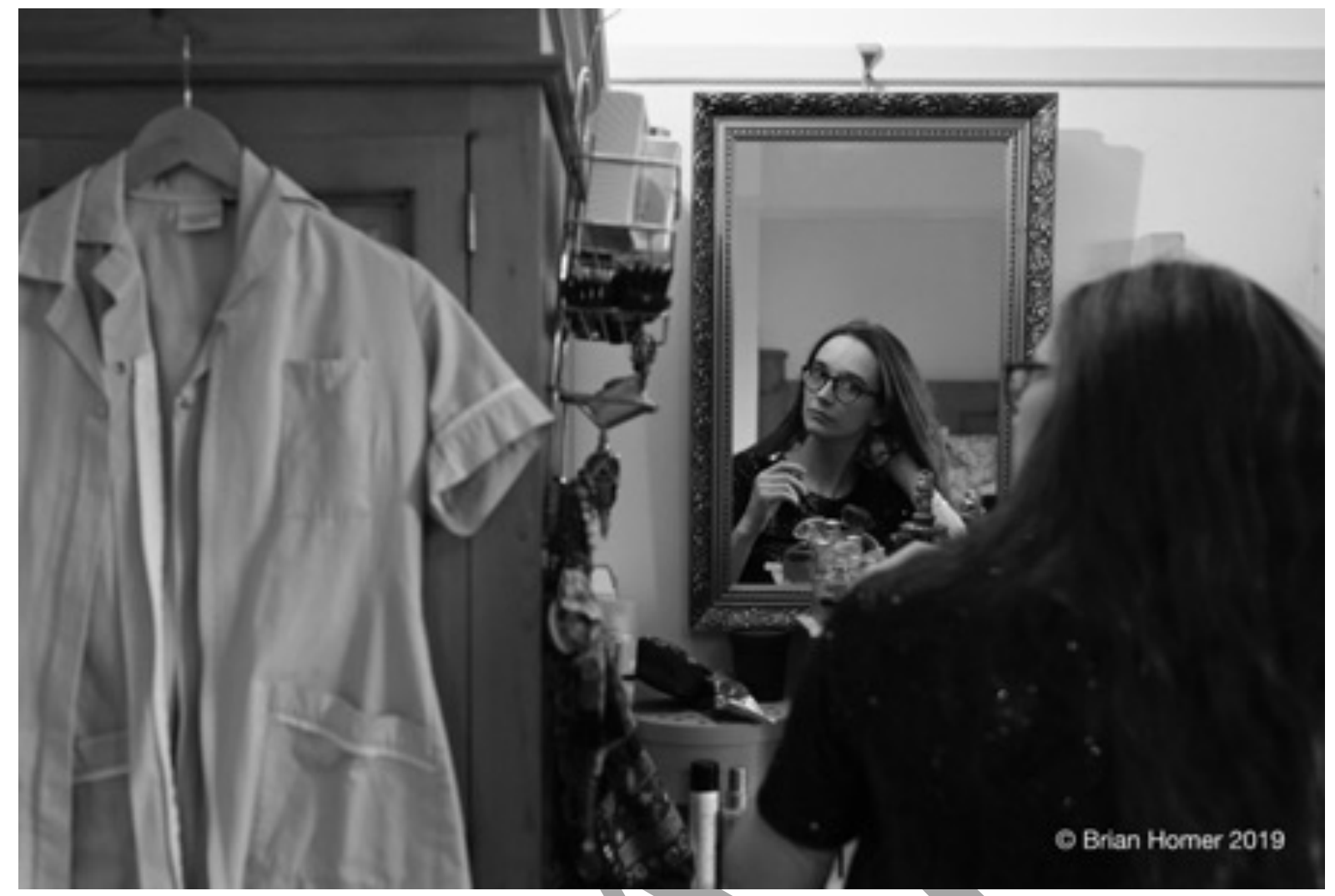

Figure 13 -Ruth, Birmingham

"It's such an unreliable profession - that's the hardest part about it. Because...you can be working lots and you can be gigging lots for several months of the year and the rest of the year is absolutely dead, there's nothing...I found myself working in the care home round the corner for minimum wage doing six hour shifts starting at half seven coming home at half one, grabbing a shower, going and picking up my son from school, teaching some children as well and then doing whatever - other work I had to do in the evenings and doing it all again the next day." (Angell 2018). ${ }^{32}$

BH: This shot was suggested by Ruth to highlight her quote. It turned out she still had the uniform despite having stopped doing shifts some months before. In this case the business of a domestic bedroom location added rather than detracted from the shot. Light was not great so I positioned a lamp on top of the wardrobe to make sure Ruth's face was lit-the window was to the right of the shot. I used the $28 \mathrm{~mm}$ prime $f 1.8$ lens set to $f 2.8$ and $1 / 160^{\text {th }}$ second shutter speed to make sure her reflection was in focus with some depth of field while putting the uniform and her face to the right out of focus to emphasise the care work was in the past but in her mind. Although shot at $28 \mathrm{~mm}$ Ruth suggested a tighter crop which does look better, so in practice this is probably the equivalent of $35 \mathrm{~mm}$.

${ }^{32}$ Angell with Cravinho (18'27”-18'41” and 19'53" - 20'13”). 


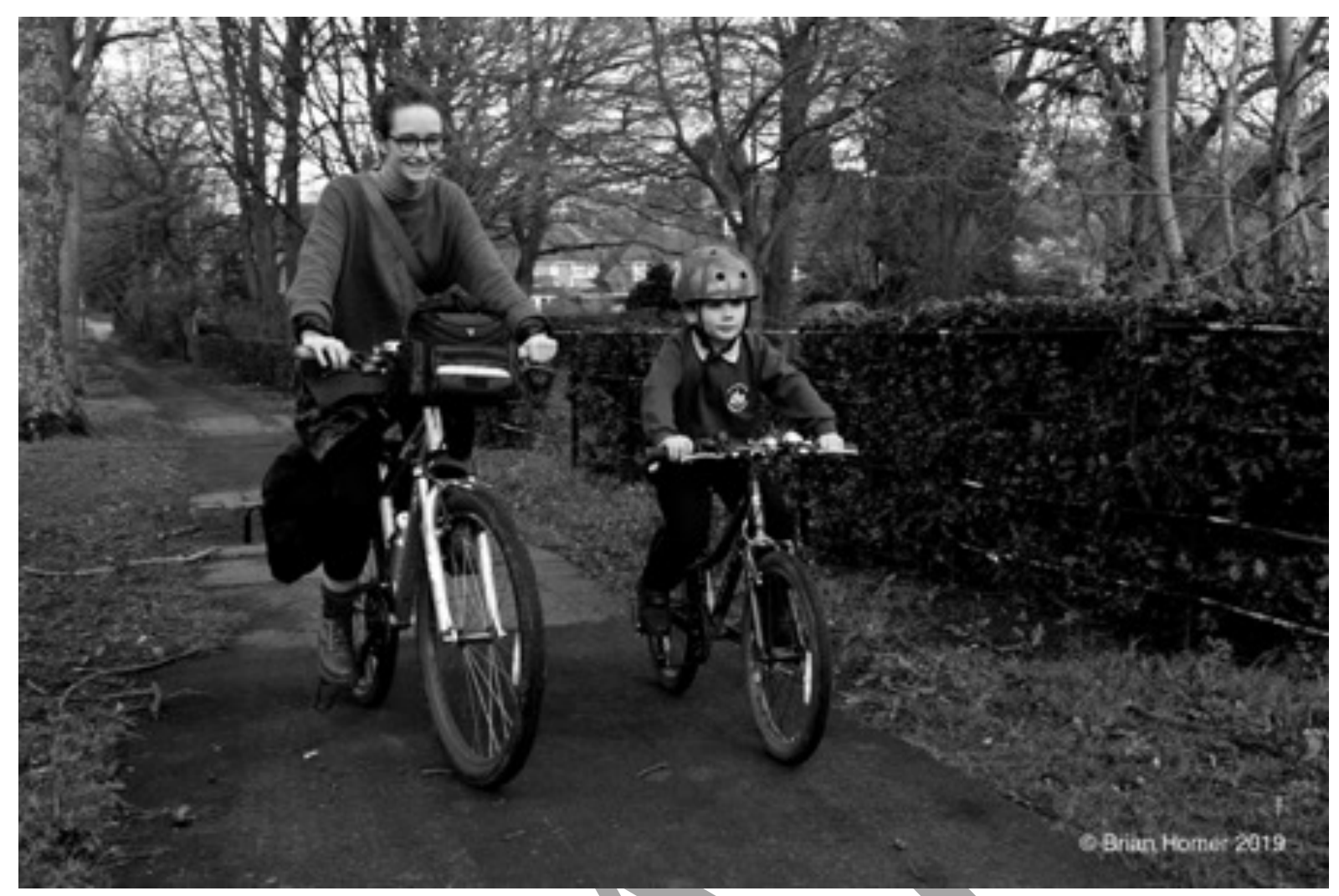

Figure 14 -Ruth and son, Birmingham

"Becoming a mother for me was an extraordinary shock to the system...You have to put your music and your art to one side. The thing is though, I never stopped working, we did London Jazz Festival when Elvin was about a month old. Pumping milk in the dressing room and thinking, what am I doing, this is just crazy. Finding it really, really difficult. Being a mother and a musician is a very difficult balance... suddenly I was like - I've got a baby! I can't just go off and tour for three or four nights in a row." (Angell 2018). ${ }^{33}$

BH: I arranged to meet them on their way back from Elvin's school to reinforce Ruth's comments. Outside lighting meant a low ISO400 and the zoom 24-70 f4 to allow me to quickly reframe as they cycled. As this was a moving subject I used the tracking focus settings on the Nikon Z6 and a small aperture of f8 and shutter speed of $1 / 160^{\text {th }}$ for sharpness. Focal length is $42 \mathrm{~mm}$. The challenge was to get a natural look for a set-up shot. So after checking my first shots this was a second pass-by where I asked them to keep closer together to get the composition and relationship between them to match the feeling from the quote.

${ }^{33}$ Ibid. (21'40”-24’00”). 


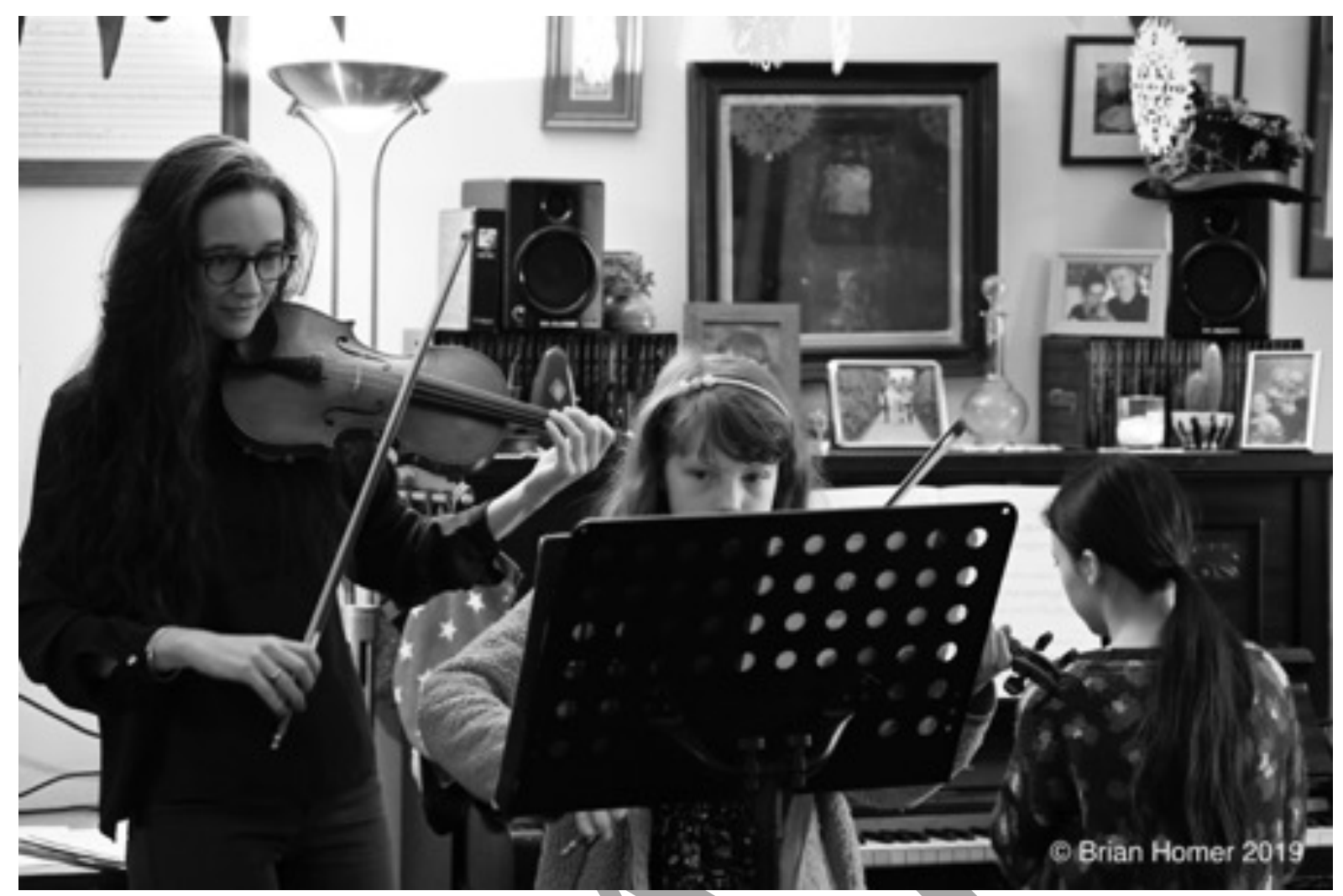

Figure 15 -Ruth teaching session, Birmingham

"I teach violin and...I've upped my teaching practice and we turned our musical activities into a proper business now. So, we work properly from home, it's a company and yeah we do that most days now, booking gigs, ringing people, sending emails, practising, writing, filling in forms, doing the whole thing." (Angell 2018). ${ }^{34}$

BH: Ruth during a session at home showcasing her students' progress to their parents.

Lighting was poor and because Ruth's living room was packed with students and their parents there was little room to work with. So I was in the doorway using 70mm on the 24$70 \mathrm{~mm}$ f4 zoom. The image is also slightly cropped to focus the composition so it's probably equivalent to $80 \mathrm{~mm}$. ISO3200 wide open at $f 41 / 125^{\text {th }}$ second. In this instance the location reflects the use of home in making a living and the family images on the piano enhance that. I debated whether the violin student's face being cut off by the music stand worked or not but decided that as she is not the main focus it was acceptable.

\section{Xhosa Cole}

${ }^{34}$ Angell with Cravinho (6’08" - 7’05'). 
Handsworth-born Xhosa Cole is an embodiment of the success of numerous community arts programmes in Birmingham. Having first played the tenor sax at Andy Hamilton's Ladywood Community Music School, he’s now among a long legacy of Birmingham saxophonists. In October 2018, he won the BBC Young Jazz Musician competition following a critically acclaimed performance in the final at the Queen Elizabeth Hall as part of the BFI London Jazz Festival. Xhosa's earliest memories of the arts are with ACE Youth Dance group. However, since playing in Holyhead School's Jazz band with Ray Prince and Sid Peacock he decided to pursue music and joined the Jazzlines Ensemble, Birmingham Schools Symphony Orchestra, Midland Youth Jazz Orchestra amongst others. While studying at Bishop Vesey's Sixth Form Xhosa attended courses with the National Youth Jazz Collective and National Youth Wind Orchestra. Xhosa has recently moved to London to pick up his studies again at Trinity College of Music with his teachers Mike Williams and Jean Toussaint. While in London Xhosa aims to reinforce the tradition in his playing connecting with the scene and its musicians while also helping to connect Birmingham to the larger UK scene.

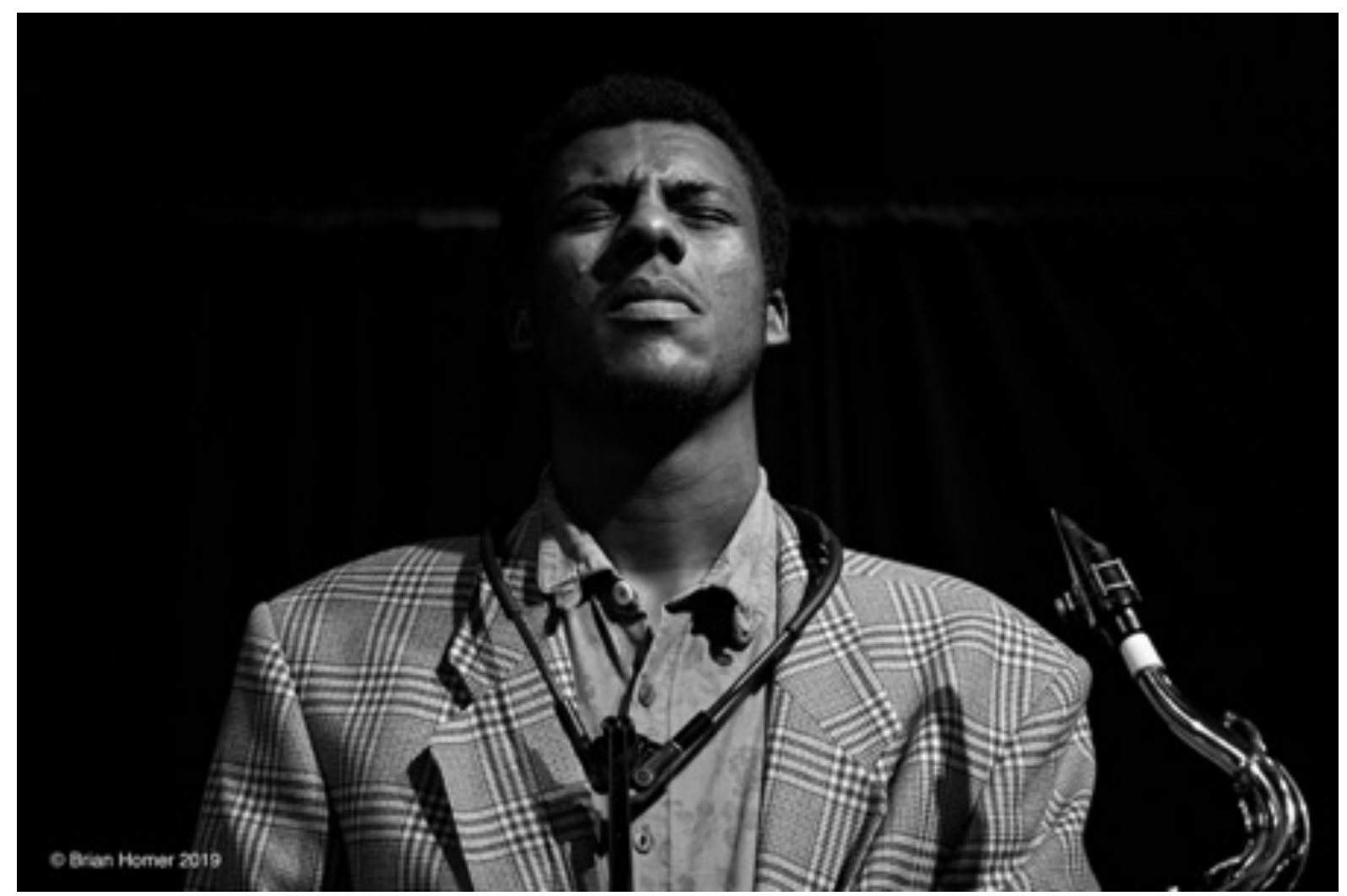

Figure 16 -Xhosa performance, Birmingham 
"One of the biggest things for me about jazz music a sense of lineage and a sense of history and a sense of family, spanning across generations and across time. There's all of our great elders and all the people who are current elders and all the people who are going to be elders. All somehow fit into this beautiful, beautiful timeline and sense of station within the music" (Cole 2019). ${ }^{35}$

$\mathrm{BH}$ : Unlike most of the photographs in this project this was taken in performance. But it was taken after the interview and I had what he said in my mind. During performances I often look for shots which are not the usual "player blowing their horn" type image. I feel this picture is very redolent of Xhosa's approach and his immersion in the music and the history of the music. It was shot a Birmingham Jazz gig and unlike most of the images in the project has no background of contextual information - this was deliberate to focus on Xhosa. Shot with the 24-70mm f4 Zoom at 70mm ISO 3200, f4.0 1/160 th second. In. performance shooting the new Nikon Z6's silent mode is very useful and enables shooting even in quiet moments.

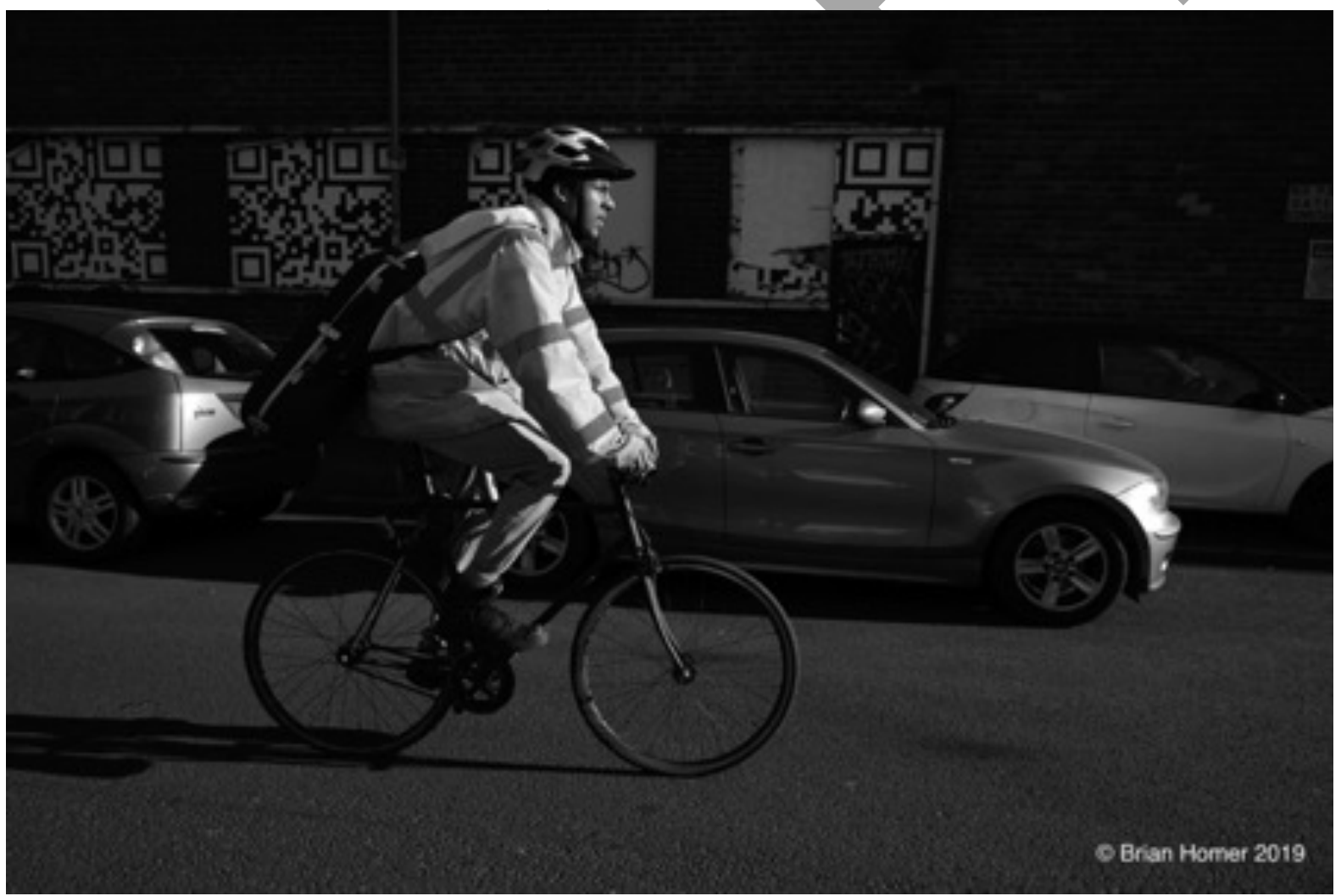

Figure 17 -Xhosa riding his bike, Birmingham

"I'm in a very fortunate position, where I'm at...because I have spent so much time, and it didn't feel like grafting or investing time at the time, it did just feel like going out to gigs and it did just feel like connecting with people naturally but over the course of the past seven or eight years...being really present on the scene, getting on my bike and going out to gigs or

\footnotetext{
${ }^{35}$ Cole with Cravinho (19'30" - 21'00”).
} 
getting on my bike coming to this room to rehearse with MYJO or getting on my bike going to the Jazzlines workshops, getting on my bike blah, blah, blah, going to places you get to know people and you get to really establish a relationship." (Cole 2019). ${ }^{36}$

BH: I wanted to give a flavour of how committed Xhosa is to the music and how he gets about the City. Again although a set-up shot I wanted to get that natural feel and got him to cycle down the street with no other instruction. To catch the movement I used tracking autofocus a high shutter speed of 1/1250 th second and a small aperture of f8.0 at ISO400. Focal length was $24 \mathrm{~mm}$ to allow me to get quite close while including the urban background.

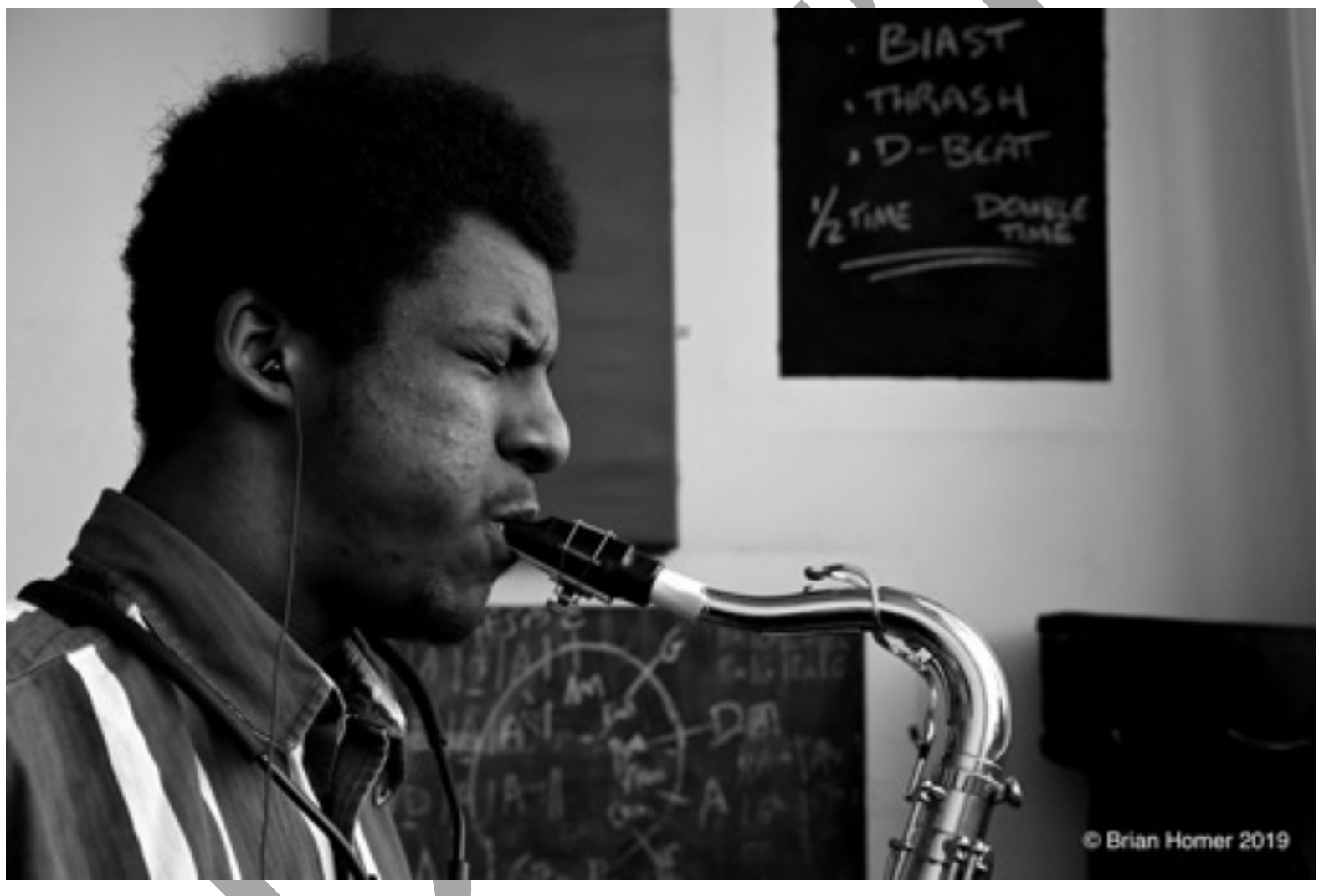

Figure 18 -Xhosa practising, Birmingham

"If I had a job title which I don't think I do, it was some ridiculous thing like semi-professional, part-time, student, apprentice musician... with this jazz mindset of wanting to push forward respects the fact that regardless of this huge accolade, I've still got to be making progress... because if I'm thinking too much about that then I'm not shedding authentically and sincerely." (Cole 2019). ${ }^{37}$

$\mathrm{BH}$ : While this is a shot of Xhosa playing it is not a performance shot - he is practising in his shared lock-up in downtown Birmingham and reflects the importance of 'shedding' to his

\footnotetext{
${ }^{36}$ Ibid. (24'18'" - 25'03'”).

${ }^{37}$ Cole with Cravinho (70'58' - 71'20').
} 
music. There are some clues in the earphones and in the background which has a cycle of fifths diagram and the other chalked messages reflecting the room's use by other musicians. I've used the 24-70 f4 zoom at f4.5 and $42 \mathrm{~mm}$ with natural window light. ISO3200 but f8 (Shutter speed $1 / 125^{\text {th }}$ second) to focus on his face and horn. I've also positioned him so that the background creates sectioned off areas with his profile and horn linking them up.

\section{Conclusion}

We suggest that photography can be a significant tool to research the off-stage living experiences of musicians. By making photographs as an output for this pilot research project we have attempted to construct 'a record about [local] culture' (Worth, 1980). The photographs show concrete details of everyday lives activities of participants and the contexts in which they occur, providing insights about participants and the living constraints while developing their careers. As Wagner suggests:

"the dialectic between the use of photographs to study human activity and the study of photographic imagery itself be kept alive. This involves a commitment on the part of those involved ... that they will use images as well as entertain questions about what they mean (Wagner, 1979: 294).

In fact, more than the photograph itself, and the way we look at it, was the context from which those fragments were captured that interested us. As Price suggests, "the photographs without a story are undistinguished in itself and unreadable in anything like the dimensions of its narrative implications" (Price, 1994: 95). Adding that,

"If description is necessary to complete the meaning of the photograph or to interpret the visual aspect by defining its elements in words, the question might arise of who is qualified so to describe (Price, 1994: 5).

In our collaborative project, the selected descriptions in words associated with each fragment captured by Homer's eyes, are comments from the participants' interviews. These concurrences - images with statements - can provide insights into participants' everyday lives. This approach addresses the recommendation made by Schwartz:

By presenting photographs with a written text which draws attention to informants' varied responses and the role of the photographer as an elicitor, viewers' proclivity to treat these pictures either as mirror images of their subjects or as aesthetic objects that might be redirected This yield of such approach would be twofold, giving the reader/viewer a way to 
understand the culture of the community under investigation, as well as a way to understand photography as a medium of communication (Schwartz, 1989: 152).

This visual approach opens up the possibility of new, or under-studied, topics for jazz studies research, for example, those concerning musicians off-stage complementary activities, social dynamics within their communities, and the living challenges and constraints.

\section{Select bibliography}

Cawthra, Benjamin. 2011. Blue Note in Black and White: Photography and Jazz. Chicago, IIl.; London: University of Chicago Press.

Escritt, Russ. 2009. Jazz in Black and White. (n.p.): Blurb.

Escritt, Russ. 2009b. Andy Hamilton, the Blue Notes and Guests. (n.p.): Blurb.

Escritt, Russ. 2010a. Jazz Photography: Colour Images 2006-2009.(n.p.): Blurb.

Escritt, Russ. 2010b. A Jazz Year in Birmingham: September 2009 to August 2010. (n.p.): Blurb.

Gabbard, Krin. 2002. "Images of jazz”. In The Cambridge Companion to Jazz, (eds.) Mervyn Cooke and David Horn. Cambridge: Cambridge University Press, 332-346.

Ings, Richard. 2003. Making Harlem Visible: Race, Photography and the American City, 19151955. Doctoral Thesis. University of Nottingham.

Jeffrey, Ian. 1992. "Fragment and Totality in Photography". History of Photography. 16-4: 351-357.

Lofland, Lyn. 1998. The Public Realm: Exploring the City's Quintessential Social Territory New York: Aldine de Gruyter.

Price, Mary. 1994. The Photograph: A Strange, Confined Space. Stanford: Stanford University Press.

Schwartz, Dona. 1989. "Visual Ethnography: Using Photography in Qualitative Research". Qualitative Sociology.12(2): 119-154.

Simpson, Jim and Ron Simpson. 2019. Don't Worry 'Bout the Bear: From the Blues to Jazz, Rock \& Roll and Black Sabbath. Studley: Brewin Books.

Sontag, Susan. 2003. Regarding the Pain of The Others. New York: Picador.

Wagner, Jon. (ed.). 1979. Images of Information: Still Photography in the Social Sciences. Beverly Hills, California: Sage. 
Watson, John. 2011. The Power of Jazz. (n.p.): Blurb.

Worth, S. 1980. "Margaret Mead and the Shift from 'Visual Anthropology' to the 'Anthropology of Visual Communication'". Studies in Visual Communication. 6(1):1522.

\section{Interviews}

Angell, Ruth with Pedro Cravinho (recorded) Birmingham 26.11.2018

Cole, Xhosa with Pedro Cravinho (recorded) Birmingham 14.1.2019

Grey, David Austin with Pedro Cravinho (recorded) Birmingham 14.1.2019

Gardener-Trejo, Alicia with Pedro Cravinho (recorded) Birmingham 14/1/2019

Young, Chris with Pedro Cravinho (recorded) Birmingham 9/10/2018

Walter, Joey with Pedro Cravinho (recorded) Birmingham 21.1.2019

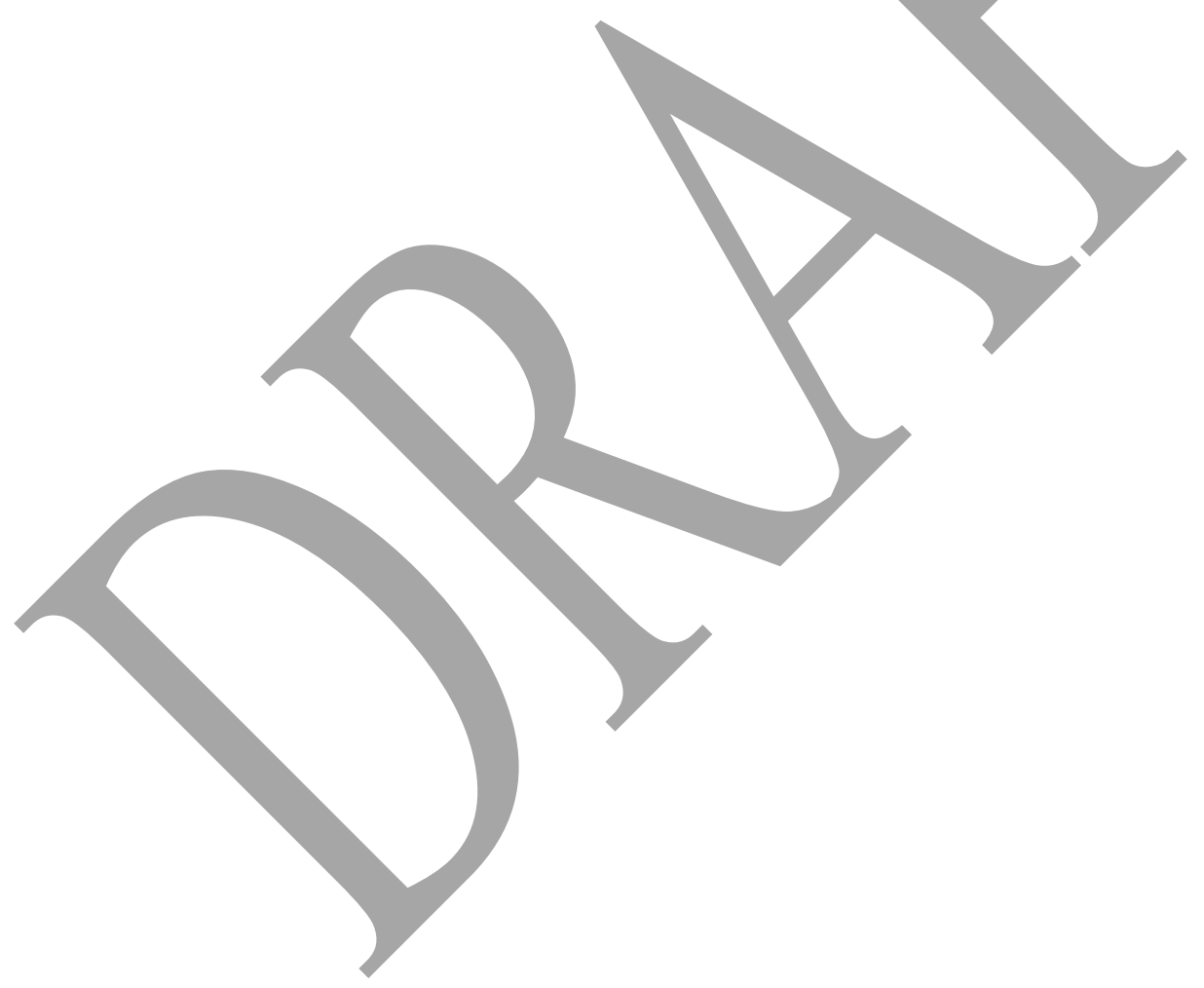

